\title{
Physical, chemical and biological variability in the Dr. C. Gelsi reservoir (NW Argentine): A temporal and spatial approach
}

\author{
B. C. Tracanna ${ }^{1-3, *}$, S. N. Martínez De Marco ${ }^{1,2}$, M. J. Amoroso ${ }^{4}$, N. Romero ${ }^{5}$, P. Chaile ${ }^{5}$ \\ \& A. Mangeaud ${ }^{6}$
}

1 ILINOA (Instituto de Limnología del Noroeste Argentino), Facultad de Ciencias Naturales e Instituto Miguel Lillo. Universidad Nacional de Tucumán. Miguel Lillo 205. C.P. 4000. San Miguel de Tucumán. Tucumán. Argentina.

2 Fundación Miguel Lillo (FML). Miguel Lillo 251. CP: 4000. San Miguel de Tucumán. Tucumán. Argentina.

3 Consejo Nacional de Investigaciones Científicas y Técnicas (CONICET).

${ }^{4}$ Cátedra de Microbiología, Facultad de Bioquímica, Química y Farmacia. (UNT). Ayacucho 475. C.P. 4000. San Miguel de Tucumán. Tucumán. Argentina.

5 Obras Sanitarias Tucumán-Laboratorio Central. Av. Sarmiento 987. San Miguel de Tucumán. Tucumán, Argentina.

${ }^{6}$ Cátedra de Estadística y Biometría. Facultad de Ciencias Exactas, Físicas y Naturales, Av. Vélez Sarsfield 299. C.P.: 5000. Córdoba. Argentina.

* Corresponding author: ilinoa@csnat.unt.edu.ar

\begin{abstract}
Physical, chemical and biological variability in the Dr. C. Gelsi reservoir (NW Argentine): A temporal and spatial approach

With the purpose of understanding the phytoplankton dynamics in two vertical profiles of the Dr. C. Gelsi reservoir (Tucumán, Argentina, monthly samplings were conducted from October 1997 to March 1999 in the limnetic zone and at the intersection of the Salí and Tapia tributary. The reservoir was characterized as warm monomictic, with bicarbonate, chloride, sodium, calcium and/or magnesium waters. In both sites total nitrogen concentration was higher than $1 \mathrm{mg} / \mathrm{l}$, whereas that of orthophosphate reached $0.2 \mathrm{mg} / \mathrm{l}$. Out of the eleven organochlorine pesticides analyzed, the presence mainly of lindane and methoxychlor, with higher concentrations in the warm months was confirmed. Bacterial load values were compatible with water quality standards, and variations in the number of actinomycetes colonies in the sediments were correlated, among other parameters, with dissolved oxygen. In the two zones studied a total of 57 phytoplankton taxa, $49 \%$ green algae, $37 \%$ diatoms, $9 \%$ Cyanobacteria and $5 \%$ dinoflagelates, were identified. Central diatoms (Aulacoseira granulata and Cyclotella meneghiniana) prevailed in the phytoplankton and, in a lesser degree, the other groups, low values of specific diversity being obtained. A principal components analysis based on the absolute abundance of species and on some physico-chemical parameters ordinated the samples of the various levels, this abundance being more evident in the limnetic zone. There was also a tendency to the separation of stratifications from the two consecutive years and homogeneity in the samples from the mixing period was noticed. On the basis of the saprobic index, water quality was from $\beta-\alpha$-mesosaprobic to $\alpha$-mesosaprobic.
\end{abstract}

Key words: Physical and chemical parameters, biological parameters, phytoplankton, reservoir, northwestern Argentina, Tucumán.

\section{RESUMEN}

Variabilidad física, química y biológica en el embalse del Dr. C. Gelsi (NW Argentina): Una aproximación temporal y espacial

Con el objeto de interpretar la dinámica del fitoplancton en dos perfiles verticales del embalse Dr. C. Gelsi (Tucumán, Argentina), se realizaron muestreos mensuales desde octubre de 1997 a marzo de 1999, en la zona limnética y en la intersección de los tributarios, ríos Salí y Tapia. El embalse fue caracterizado como monomíctico cálido, con aguas bicarbonatadas, cloruradas, sódicas, cálcicas y/o magnésicas. En ambos sitios, la concentración media de nitrógeno total fue superior a $1 \mathrm{mg} / \mathrm{l}$, mientras que la de ortofosfato llegó a $0.2 \mathrm{mg} / \mathrm{l}$. De los once plaguicidas organoclorados analizados se 
comprobó, principalmente, la presencia de lindano y metoxicloro, con concentraciones más elevadas en los meses cálidos. Los valores de carga bacteriana fueron compatibles con las normas de calidad de agua y las variaciones del número de colonias de actinomycetes en los sedimentos estuvieron correlacionadas entre otros parámetros con el oxígeno disuelto. En las dos zonas estudiadas se identificaron un total de 57 taxones: $49 \%$ algas verdes, $37 \%$ diatomeas, $9 \%$ Cyanobacteria y $5 \%$ dinoflagelados. Las diatomeas centrales (Aulacoseira granulata y Cyclotella meneghiniana) predominaron en el fitoplancton y en menor orden, los otros grupos, obteniéndose bajos valores de diversidad específica. Los análisis de componentes principales basados en la abundancia absoluta de las especies y en algunos parámetros fisicoquímicos, ordenaron las muestras de los distintos niveles, siendo ésta más evidente en la zona limnética. Asimismo, hubo una tendencia a la separación de las estratificaciones de los dos años consecutivos y se observó homogeneidad en las muestras provenientes del período de mezcla. Sobre la base del índice sapróbico, la calidad del agua fue $\beta-\alpha$-mesosapróbicas a $\alpha$-mesosapróbicas.

Palabras clave: Parámetros físicos y químicos, parámetros biologicos, fitoplancton, embalse, Noroeste Argentino, Tucumán.

\section{INTRODUCTION}

Canevari et al., 1998 divided Argentina in six regions that group humid zones with similar ecological characteristics. The Dr. C. Gelsi reservoir (El Cadillal) located in northwestern Argentina is included in the "chaqueña" region, one of the vastest regions in South America. In this plain, rainfalls decrease from the east to the west and the rain regime is seasonal with higher precipitations during summer and a dry period in winter that is longer in the west. Chaco falls into three regions: eastern, central, and western (Bucher, 1980; Cabrera \& Willink, 1973). The area studied is located in the latter where water courses start in the Andean, Subandean, and Pampean mountain systems located to the west of Chaco. Some rivers of this system flow into important closed basins. The Salí-Dulce River, which stands out, feeds together with the Suquía and Xanaes Rivers from Córdoba, the largest South American endorreic basin that ends in the Mar Chiquita lagoon with an approximate surface area of 6400 $\mathrm{km}^{2}$ (Bucher \& Chani, 1998). The Dr. C. Gelsi reservoir belongs to this system together with other dams such as La Angostura, Escaba, and Río Hondo among others.

Dam building constitutes one of the main ways of modification of man-made water basins. The benefits of these works are eventually accompanied by adverse environmental alterations that can often be minimized by suitable planning.

The serious decay of the Salí-Dulce basin due to the silting up of dams with values of up to
$68 \%$ (Kruse et al., 1994), the recurrent eutrophication, with extended anoxia periods, $\mathrm{BOD}_{5}$ high values of up to $1220 \mathrm{mg} / \mathrm{l}$, the density of total coliform bacteria of up to $10.2 \log \mathrm{NMP} / 100 \mathrm{ml}$ (Romero et al., 1994), and the supply of total industrial solids of 334833 metric tons/year should be all pointed out. Today the problem is aggravated because of the increase of mining exploitations with the consequent pouring of effluents that alter water quality.

Among the previous works done in the Dr. C. Gelsi reservoir, those of the Consejo Federal de Inversiones (1962), the Instituto de Arquitectura y Planeamiento-Universidad Nacional de Tucumán (1967), and Díaz Rueda (1988), referred to the ecological characterization of this water body, and the compilations or measurements of abiotic data are quoted. Regarding the research papers, those of Tracanna et al., (1991); Tracanna \& Seeligmann (1992); Seeligmann \& Tracanna (1994); Locascio et al., (1997); Tracanna et al., (1996), and Martínez De Marco \& Tracanna (2001) have to be cited. These works present the physical and chemical characterization of this reservoir as well as the ecology of phytoplankton for the 1987-1988 period.

Amoroso et al. (1997) also studied the presence of Mn (II) in the dam at various depths and determined that strains of actinomycetes isolated from water sediments were able to detect manganese concentrations of up to $1.5 \mathrm{ppm}$.

The aim of this paper was to study the phytoplankton structure in two vertical profiles of the Dr. C. Gelsi reservoir for the 1997-1998 period 


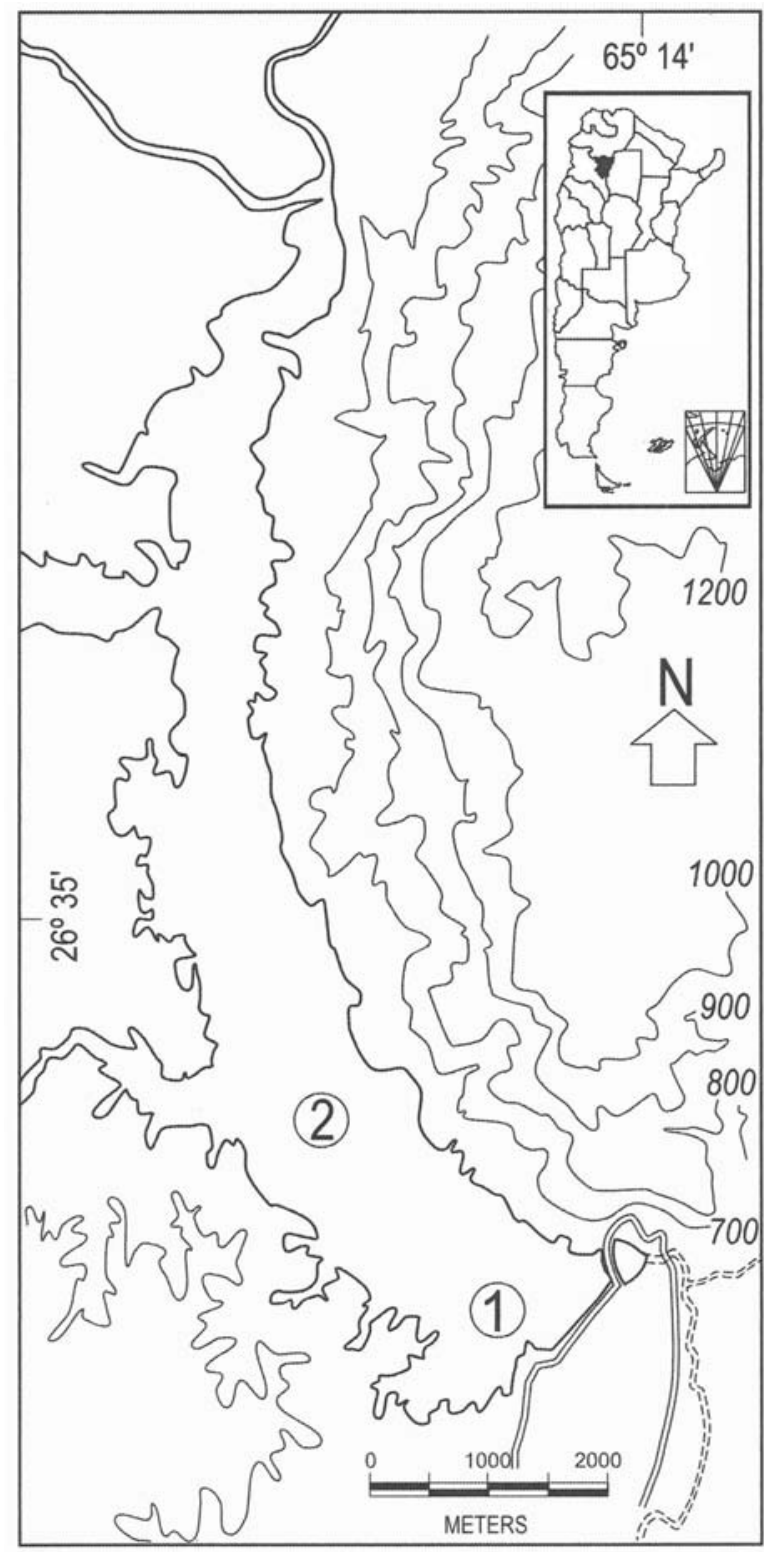

Figure 1. Location of sampling sites in the Dr. C. Gelsi reservoir 1.-limnetic zone (ZI); 2.-intersection zone of tributaries (ZIR). Ubicación de los sitios de muestreo del embalse Dr. C. Gelsi 1.-zona limnética (ZI); 2.-zona de intersección de los tributarios (ZIR).

in relation with physical, chemical and biological parameters. Actinomycetes from the sediment were also evaluated, and an analysis of organochlorine pesticides as possible disturbers of water quality was included.

\section{Description of the studied site}

The Dr. C. Gelsi reservoir is located $26 \mathrm{~km}$ to the north of the city of San Miguel de Tucumán, Argentina, between $26^{\circ} 40^{\prime} \mathrm{S}$ and $65^{\circ} 7^{\prime} \mathrm{W}$. It is $8 \mathrm{~km}$ long and has a maximal width of $1 \mathrm{~km}$; it is sub-rectangular and elongated in a N-S direction. The water surface area is 1062.30 ha at $607.50 \mathrm{~m}$. a.s.l., its volume being $216.80 \mathrm{hm}^{3}$. Its maximal depth is $50 \mathrm{~m}$, with an average of $27.8 \mathrm{~m}$. Residence time is 0.51 years (Calcagno $\mathrm{et}$ al., 1995). The climate is subhumid-humid with little to no water deficit. Rainfalls are heavy from December to March. The reservoir is placed on continental sedimentary rocks from The Upper Tertiary Period. These are sandstones and slimes with gypsum bank insertions. This reservoir was built in order to use its waters for many purposes: swelling decrease, regulation of natural irrigation flows, drinking water supply, generation of hydro-electrical power, recreation and tourism. From a phytogeographic viewpoint the vegetation of this area is represented in its western sector by the "chaqueño" mountain forest and transition elements. In its eastern sector the prevalence of a deciduous forest on the western slopes and of the evergreen forest on the slopes exposed to the south and southeast can be seen (Tracanna $e t$ al., 1991; Locascio et al., 1997. Residence time is 0.51 years (Calcagno et al., 1995).

\section{MATERIALS AND METHODS}

Two sampling stations were selected in the reservoir: the integration or limnetic zone (ZI) and the intersection zone of the Tapia and Salí rivers (ZIR), these having an average depth of 39 and $21 \mathrm{~m}$, respectively (Fig. 1).

From October 1997 to March 1999 eighteen samplings were carried out. In every one of them data on temperature, $\mathrm{pH}$, turbidity, conductivity, and dissolved oxygen (DO) vertical profiles through the use of a multi-parametric probe (Hydrolab: DataSonde 3, Water Quality Multiprobe Logger, Austin TX, USA) were taken in situ and the Secchi depth was also measured.

Samples for chemical and biochemical oxy- 
gen demand $\left(\mathrm{BOD}_{5}\right)$ analyses were taken from three levels: the surface, either at $10 \mathrm{~m}(\mathrm{ZI})$ or at $5 \mathrm{~m}$ (ZIR) and the bottom, the depth of the latter being dependent on the quantity of dammed up water; extractions were performed by means of a Schindler-Patalas-type trap. From the same levels phytoplankton samples were taken for analyses. The determination of bacterial load was carried out on surface waters whereas organochlorine compounds where determined in samples from the bottom.

The methodologies followed for the analyses of anions and cations, silica, manganese, inorganic nitrogenous (nitrate, nitrite, ammonium), orthophosphate, organic matter, biochemical oxygen demand, and bacterial load (total and faecal coliforms and Streptococcus faecalis) agree with APHA, 1992.

Organochlorine pesticides (OP), aldrin, dieldrin, chlordane, DDT (total + isomers), DDD, DDE, heptachlor, epoxides, lindane and methoxychlor were analyzed with a capillary column gas chromatograph (HP-5).

Sediment samples to determine the concentration of actinomycetes population were taken by means of a dredge and were kept at $4{ }^{\circ} \mathrm{C}$ until processed. They were later diluted with sterile distilled water and seeded in a selective complex culture medium; $\mathrm{pH}$ was adjusted to 7 before their sterilization. The medium was supplemented with cycloheximide and nalidixic acid $10 \mu \mathrm{g} / \mathrm{l}$ in order to inhibit the growth of fungi and Gramnegative bacteria, respectively. Plates were incubated at $25{ }^{\circ} \mathrm{C}$ for 10 days followed by a count of actinomycetes colonies.

The analysis of the organic matter of sediment samples was carried out by oxidation with $\mathrm{K}_{2} \mathrm{Cr}_{2} \mathrm{O}_{7}$ (Jackson, 1970).

In order to assess chlorophyll $a, 5$ liters of water were filtered through Whatman GF/C fiber-glass filters with a vacuum pump in the dark within 24 hours following the sampling. Filters were kept at $-20{ }^{\circ} \mathrm{C}$ and at the time of extraction methanol was used as a solvent. Extracts were read at 665 and $750 \mathrm{~nm}$ before and after being acidified, and the quantity of chlorophyll $a(\mu \mathrm{g} / \mathrm{l})$ was estimated using Talling \& Driver's formula (Loez, 1995).
Qualitative samples were taken with a plankton net (size: $20 \mu \mathrm{m}$ ) by means of horizontal sweepings at different depths, and quantitative samples were taken directly from the surface and in a stratified way. The samples assigned to taxonomic identification were fixed with $4 \%$ formalin and those used for a quantitative analysis with acetic Lugol's solution. The phycoflora counts were carried out in duplicate with an inverted microscope using Utermöhl's method (1958), a fixed number of randomly selected fields (systematic type) were counted, a maximal $20 \%$ error being accepted (1-5\% being more frequent). The unicellular, colonial, and filamentous algae were considered as a unit (individual). Specific diversity was estimated according to Shannon \& Wiener (1963). For estimating the algae biomass, the biovolume was calculated using the stereometric formulas according to Rott (1981) and others; to get these results for each species their cellular shape was considered similar to a geometric form. The obtained volumetric values were then multiplied by the average cell numbers of each species. The results obtained were expressed as fresh weight $(\mathrm{mg} / \mathrm{l})$ considering the specific weight equal to a unit.

For the estimation of water quality related to the phytoplankton, Pantle \& Buck's (1955) saprobic index (Is) was used by means of the formula $I s=(s \cdot h) / h$, where $h$ corresponds to algal density and $s$ to the estimated saprobic grade according to $\mathrm{BOD}_{5}$ and to the saprobicity levels given by Hamm (1969).

Principal Components Analysis (PCA) were conducted for every sampling zone with algal densities at the three depth levels and physical and chemical parameters such as temperature, $\mathrm{pH}$, conductivity, $\mathrm{DO}, \mathrm{BOD}_{5}$, nitrate and orthophosphate (normalized and standardized values). Out of the total quantified taxa (57 species), 17 were selected after removing those that were less frequent or rare ( $\leq 3$ samples) and less abundant $(\leq 2 \mathrm{ind} / \mathrm{ml})$. This criterion was adopted because the random and rare species could result in a low confidence. Out of the species considered, 13 were common for both sites; Planktosphaeria gelatinosa and Staurastrum sp in $\mathrm{ZI}$, and Coelastrum microporum 
Table 1. Correlation analysis between some physical and chemical variables of the limnetic zone of the Dr. C. Gelsi reservoir. Abbreviations used correspond to: VOL: volume; TRA: transparency; DO: dissolved oxygen; TEM: temperature; TUR: turbidity; CON: conductivity; IN: inorganic nitrogen; ACT: actinomycetes; ABU: algal abundance; CLO: chlorophyll $a$; and DI: specific diversity. Análisis de correlación entre algunas variables fisicas y químicas de la zona limnética del embalse Dr. C. Gelsi. Las abreviaturas utilizadas corresponden a: VOL.: volumen; TRA.: transparencia; OD: oxígeno disuelto; TEM.: temperatura; TUR.: turbidez; CON.: conductividad eléctrica; IN.: nitrógeno inorgánico; ACT.: Actinomycetes; ABU.: abundancia algal; CLO.: clorofila a; DI.: diversidad específica.

\begin{tabular}{|c|c|c|c|c|c|c|c|c|c|c|c|c|c|c|c|c|c|}
\hline VOL. & TRA. & DO & TEM. & $\mathbf{p H}$ & TUR. & CON. & Mn & $\mathrm{NO}_{3}$ & $\mathrm{NO}_{2}$ & IN & $\mathbf{S i}$ & Si:P & $\mathbf{N}: \mathbf{P}$ & ACT. & ABU. & CLO. & DI. \\
\hline VOL. & 1 & & & & & & & & & & & & & & & & \\
\hline TRA. & $.40^{* *}$ & 1 & & & & & & & & & & & & & & & \\
\hline DO & $.45^{* *}$ & $.49^{* *}$ & 1 & & & & & & & & & & & & & & \\
\hline TEM. & & $-.65^{* *}$ & & 1 & & & & & & & & & & & & & \\
\hline $\mathrm{pH}$ & & $.42^{* *}$ & $.81^{* *}$ & & 1 & & & & & & & & & & & & \\
\hline TUR. & & $-.46^{* *}$ & & $.33^{*}$ & & 1 & & & & & & & & & & & \\
\hline CON. & $-.67^{* *}$ & & $-.30^{*}$ & & & $-.45^{* *}$ & 1 & & & & & & & & & & \\
\hline $\mathrm{Mn}$ & & & $-.57^{* *}$ & & & & & 1 & & & & & & & & & \\
\hline $\mathrm{NO}_{3}$ & $.38^{* *}$ & & & & & $.40^{* *}$ & $-.56^{* *}$ & & 1 & & & & & & & & \\
\hline $\mathrm{NO}_{2}$ & & $-.36^{*}$ & $-.35^{*}$ & $.29^{*}$ & & & & & & 1 & & & & & & & \\
\hline IN & $.31^{*}$ & & & & & $.40^{* *}$ & $-.53^{* *}$ & & $.93^{* *}$ & & 1 & & & & & & \\
\hline $\mathrm{Si}$ & & $-.48^{* *}$ & $-.32^{*}$ & & $-.39^{* *}$ & $.30^{*}$ & $-.29^{*}$ & & $.42^{* *}$ & & $.49^{* *}$ & 1 & & & & & \\
\hline Si:P & & & & & & & $.30^{*}$ & & $-.32^{*}$ & & $-39^{* *}$ & $-.34^{*}$ & 1 & & & & \\
\hline $\mathrm{N}: \mathrm{P}$ & & & & & $.30^{*}$ & & & & & & $-.37^{*}$ & $-.49^{* *}$ & $.96^{* *}$ & 1 & & & \\
\hline ACT. & $-.56^{*}$ & & $-.62^{*}$ & & $-.54^{*}$ & & & & & & & & & & 1 & & \\
\hline ABU. & & & $.33^{*}$ & & $.39^{* *}$ & & & & $-.32^{*}$ & & $-.32^{*}$ & $-.49^{* *}$ & & $.35^{*}$ & & 1 & \\
\hline CLO. & & & $.36^{* *}$ & $.33^{*}$ & $.37^{* *}$ & & & & & $.44^{* *}$ & & $-.33^{*}$ & & $.32^{*}$ & & $.74^{* *}$ & 1 \\
\hline DI. & & $-.28^{*}$ & & & & & & & $.41^{* *}$ & & $.45^{* *}$ & $.44^{* *}$ & & & & $-.60^{* *}$ & $-.34^{*} \quad 1$ \\
\hline
\end{tabular}

Table 2. Correlation analysis between some physical and chemical variables of the river intersection zone of the Dr. C. Gelsi reservoir. Abbreviations used correspond to: VOL: volume; TRA: transparency; DO: dissolved oxygen; TEM.: temperature; TUR.: turbidity; COND.: conductivity; IN: inorganic nitrogen; ACT: actinomycetes; ABU: algal abundance; CLO: chlorophyll $a$; and DI: specific diversity. Análisis de correlación entre algunas variables fisicas y químicas de la zona de intersección de los ríos del embalse Dr. C. Gelsi. Las abreviaturas utilizadas corresponden a: VOL.: volumen; TRA.: transparencia; OD: oxígeno disuelto; TEM.: temperatura; TUR.: turbidez; CON.: conductividad eléctrica; IN.: nitrógeno inorgánico; ACT.: Actinomycetes; ABU.: abundancia algal; CLO.: clorofila a; DI.: diversidad específica.

\begin{tabular}{|c|c|c|c|c|c|c|c|c|c|c|c|c|c|c|c|c|c|c|}
\hline VOL. & TRA. & DO & TEM. & pH & TUR. & CON. & Mn & $\mathrm{NO}_{3}$ & $\mathrm{NO}_{2}$ & IN & $\mathbf{S i}$ & Si:P & $\mathrm{N}: \mathrm{P}$ & $\mathbf{P O}_{\text {petb } 4}$ ACT. & ABU. & CLO. & DI. & \\
\hline $\begin{array}{l}\text { VOL. } \\
\text { TRA. }\end{array}$ & 1 & & & & & & & & & & & & & & & & & \\
\hline TRA. & & 1 & & & & & & & & & & & & & & & & \\
\hline DO & $.38^{* *}$ & & 1 & & & & & & & & & & & & & & & \\
\hline TEM. & $-.39^{* *}$ & $-.63^{* *}$ & $-.31^{*}$ & 1 & & & & & & & & & & & & & & \\
\hline $\mathrm{pH}$ & & & $.65^{* *}$ & & 1 & & & & & & & & & & & & & \\
\hline TUR. & & $-.59^{* *}$ & $-.42^{* *}$ & $.55^{* *}$ & $-.67^{* *}$ & 1 & & & & & & & & & & & & \\
\hline CON. & $-.73^{* *}$ & & $-.33^{*}$ & & $.32^{*}$ & & 1 & & & & & & & & & & & \\
\hline $\mathrm{Mn}$ & & & $-.87^{* *}$ & & & & & 1 & & & & & & & & & & \\
\hline $\mathrm{NO}_{3}$ & $.40^{* *}$ & & & & $-.35^{* *}$ & $.29^{*}$ & $-.61^{* *}$ & & 1 & & & & & & & & & \\
\hline $\mathrm{NO}_{2}$ & $-.32^{*}$ & & & & & & $.39^{* *}$ & & & 1 & & & & & & & & \\
\hline IN & $.31^{*}$ & & & & $-.40^{* *}$ & $.34^{*}$ & $-.55^{* *}$ & & $.98^{* *}$ & & 1 & & & & & & & \\
\hline $\mathrm{Si}$ & & & $-.30^{*}$ & & $-.33^{*}$ & $.41^{* *}$ & $-.28^{*}$ & & $.49^{* *}$ & & $.56^{* *}$ & 1 & & & & & & \\
\hline Si:P & & & & & & & & & $-.42^{* *}$ & & $-.46^{* *}$ & $-.50^{* *}$ & 1 & & & & & \\
\hline $\mathrm{PO}_{4}$ & & & & & $-.45^{* *}$ & & & & & & & & $-.68^{* *}$ & 1 & & & & \\
\hline $\mathrm{N}: \mathrm{P}$ & & & & & & & & & $-.30^{*}$ & & $-.35^{*}$ & $-.59^{* *}$ & & $-.59^{* *}$ & 1 & & & \\
\hline ACT. & & & & & & & & & & & & & & & & 1 & & \\
\hline ABU. & & & $.40^{* *}$ & & $.36^{* *}$ & $-.36^{* *}$ & & & $-.36^{* *}$ & & $-.42^{* *}$ & $-.53^{* *}$ & & & & & 1 & \\
\hline CLO. & & & $.37^{* *}$ & & & & & & $-.41^{* *}$ & & $-.47^{* *}$ & $-.65^{* *}$ & $.46^{* *}$ & & $.49^{* *}$ & $.64^{*}$ & $.67^{* *}$ & 1 \\
\hline DI. & & & $-.31^{*}$ & $.30^{*}$ & & $.34^{*}$ & & & & & $.31^{*}$ & $.56^{* *}$ & & & & & $-.55^{* *}$ & $-.42^{* *} \quad 1$ \\
\hline
\end{tabular}




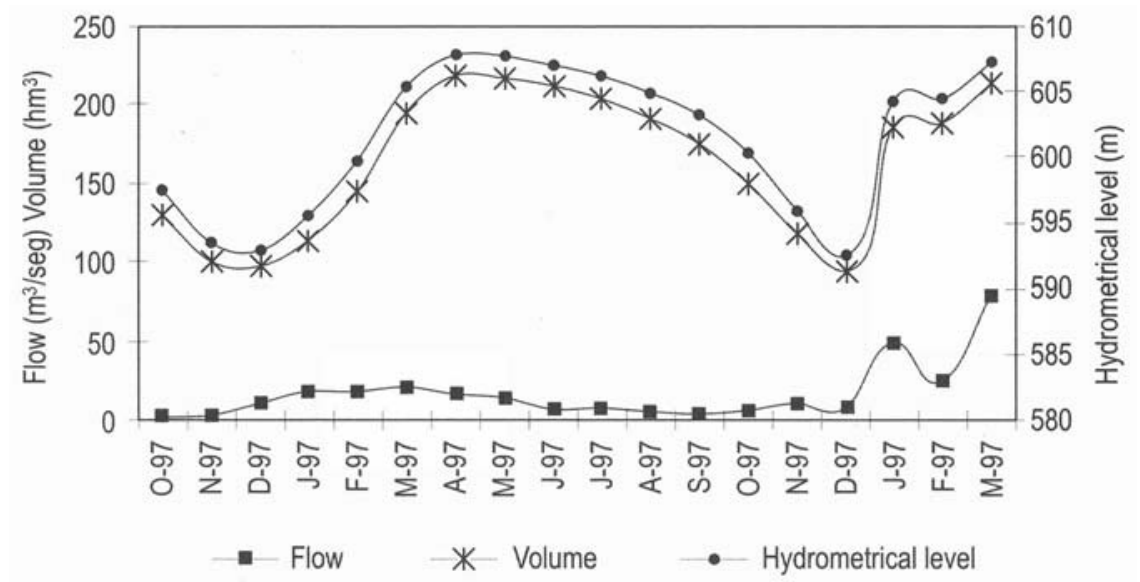

Figure 2. Variations of water level, flow, and volume (1997-1999) in the Dr. C. Gelsi reservoir. Variaciones de cota, caudal y volumen (1997-1999) del embalse Dr. C. Gelsi.

and Peridinium volzii in ZIR were also included. In order to establish correlations between pairs of variables, Pearson's correlation coefficient was used. Data were processed using the NTSYS (Rolf, 1990) statistical package.

A correlation statistical analysis (Pearson's coefficient) between physical, chemical and biological variables was performed, and the first three PCA components effected with algal densities by using the SPSS program were included. In this work the correlations that proved to be significant $(p<0.05$ and $p<0.01)$ are explained.

\section{RESULTS}

Variations in water level, volume, and flow (October/97-March/99) (Fig. 2) showed that the first two parameters had their minimal records in December/98 with $592.40 \mathrm{~m}$ a.s.l.and 94.40 $\mathrm{hm}^{3}$ and their maximal records in April/98 with $607.62 \mathrm{~m}$ a.s.l. and $218.05 \mathrm{hm}^{3}$, respectively. Regarding flow, the minimum was observed in November/97 with $1.98 \mathrm{~m}^{3} / \mathrm{s}$ and the maximum in March $/ 99$ with $78.63 \mathrm{~m}^{3} / \mathrm{s}$.

Maximal Secchi's disk depths (Fig. 3) were generally obtained from March to October 1998, ranging between 1.2 and 2.47 in ZI, and between 1.27 and $2 \mathrm{~m}$ in ZIR. Minimal values registered for both sites were $0.17-0.23 \mathrm{~m}$. Transparency had a highly significant positive correlation with volume, dissolved oxygen, and $\mathrm{pH}$, a negative correlation with temperature, turbidity, and silica dioxide, a significant negative correlation with nitrite, a specific diversity in ZI, and a highly significant negative correlation with temperature and turbidity in ZIR (Tables 1 and 2).

Annual thermal behavior defines the reservoir as monomictic, with a stratification period from October to February, with the beginning of the mixing period in March. The highest temperature difference was observed in ZI in December/97 and in October/98, with a thermocline between 5 and $10 \mathrm{~m}$ deep, a $5{ }^{\circ} \mathrm{C}$ decrease being registered. In ZIR, stratification was less evident due to its lower depth and water flow because this is a confluence zone of the rivers.

The concentration of hydrogen ions was, in general, slightly higher on the surface than in depth layers in both sampling sites, this difference being higher in the stratification period. PH records in ZI ranged between 8.87 in October/97 (on the surface) and 7.78 in November and December/97 (at a depth of 35 $\mathrm{m}$ ), whereas in ZIR they ranged between 8.86 in October/97 (on the surface) and 7.50 in March/99 (at a depth of $10 \mathrm{~m}$ ).

Maximal ZI and ZIR values of conductivity were $1520 \mu \mathrm{S} / \mathrm{cm}$ at December/97, on the surface for both and in November/97, at a depth of $5 \mathrm{~m}$ only for ZIR; minimal conductivity values were $505 \mu \mathrm{S} / \mathrm{cm}$ for ZI, and $541 \mu \mathrm{S} / \mathrm{cm}$ for ZIR, both in 
Table 3. Number of observations, minimal, maximal, and average values, and standard deviations of cations, anions, nitrogen compounds, and orthophosphate from October 1997 to March 1999 in the two zones considered. Número de observaciones, mínimos, máximos, promedios y desviaciones estándares de los cationes, aniones, compuestos nitrogenados y ortofosfato desde octubre de 1997 a marzo de 1999 en las dos zonas consideradas.

\begin{tabular}{|c|c|c|c|c|c|c|c|c|c|c|}
\hline \multirow[t]{2}{*}{ Variables (mg/l) } & \multicolumn{5}{|c|}{ ZI } & \multicolumn{5}{|c|}{ ZIR } \\
\hline & $\mathrm{n}$ & $\min$. & $\max$. & $\mathrm{X}$ & $\mathrm{sd}$ & $\mathrm{n}$ & $\min$. & $\max$. & $\mathrm{X}$ & $\mathrm{sd}$ \\
\hline Carbonate & 54 & 0 & 30 & 3 & 6 & 54 & 0 & 36 & 3 & 5 \\
\hline Bicarbonate & 54 & 112 & 189 & 159 & 18 & 54 & 112 & 180 & 158 & 17 \\
\hline Sulfate & 54 & 41 & 237 & 109 & 55 & 54 & 49 & 229 & 103 & 43 \\
\hline Chloride & 33 & 46 & 214 & 140 & 41 & 33 & 64 & 214 & 140 & 38 \\
\hline Sodium & 43 & 46 & 260 & 139 & 40 & 43 & 55 & 219 & 140 & 38 \\
\hline Potassium & 43 & 3 & 10 & 5 & 1 & 43 & 4 & 8 & 5 & 1 \\
\hline Calcium & 54 & 4 & 80 & 29 & 21 & 54 & 4 & 63 & 23 & 18 \\
\hline Magnesium & 36 & 3 & 47 & 24 & 13 & 36 & 5 & 46 & 25 & 10 \\
\hline Silica dioxide & 54 & 7 & 22 & 16 & 3 & 54 & 7 & 22 & 15 & 3 \\
\hline Total manganese & 54 & $<0.02$ & 0.7 & 0.2 & 0.2 & 54 & $<0.02$ & 0.6 & 0.1 & 0.1 \\
\hline Inorganic nitrogen & 54 & 0.76 & 1.86 & 1.19 & 0.26 & 54 & 0.8 & 1.8 & 1.2 & 0.3 \\
\hline Nitrate & 54 & 0.6 & 1.84 & 1.12 & 0.27 & 54 & 0.7 & 1.8 & 1.2 & 0.3 \\
\hline Nitrite & 54 & $<0.01$ & 0.5 & 0.06 & 0.09 & 54 & $<0.01$ & 0.2 & 0.03 & 0.03 \\
\hline Ammonium & 54 & $<0.05$ & 0.09 & 0.06 & 0.02 & 54 & $<0.05$ & 0.13 & 0.06 & 0.03 \\
\hline Orthophosphate & 54 & $<0.004$ & 15.6 & 0.45 & 2.31 & 54 & $<0.004$ & 0.28 & 0.12 & 0.06 \\
\hline $\mathrm{Si}: \mathrm{P}$ & 44 & 2 & 1742 & 437 & 439 & 45 & 107 & 1583 & 308 & 253 \\
\hline $\mathrm{N}: \mathrm{P}$ & 44 & 0.1 & 184 & 31 & 36 & 45 & 7 & 169 & 24 & 25 \\
\hline
\end{tabular}

Abbreviations: $\mathrm{n}=$ number of observations; $\min .=$ minimum; max. = maximum; $\mathrm{X}=$ average; $\mathrm{sd}=$ standard deviation

March/99, at the bottom. It was observed that the temporal-spatial conductivity value profiles diminish with depth; however an evident increase of these values was detected in the hypolimnion in January and February/98-99 for ZI and ZIR, and in November/98 only for ZIR. The time evolution of the average value of conductivity in the water column for both sites is observed in figure 5. Minimal registers at the end of summer/98 and 99 and fall/98 gradually increase in the beginning of summer. In ZI significant positive correlations with $\mathrm{Si}: \mathrm{P}$ were obtained, highly significant negative correlations were found with volume, turbidity, nitrate, inorganic nitrogen, and significant ones with DO and silica dioxide; in ZIR highly significant positive correlations were found with nitrite, significant ones with $\mathrm{pH}$, highly significant negative correlations with nitrate, volume, and inorganic nitrogen, and significant ones with DO and silica dioxide (Tables 1 and 2).

Turbidity (as National Units of Turbidity (NUT)) ranged between 1.6 in September/98 (on the surface) and 53.6 in March/99 (at the bottom) in ZI, and between 0 for December/98 (on the surface) and 47.9 in December/97 (at a depth of $10 \mathrm{~m}$ ) in ZIR.

The distribution of dissolved oxygen concen- tration in the profile was closely related to the stratification and mixing periods (Fig. 4). Maximal DO values were obtained on the surface in November/98 with $10.26 \mathrm{mg} / \mathrm{l}$ in ZI and in July/98 with $10.65 \mathrm{mg} / \mathrm{l}$ in ZIR. Minimal records were obtained at the bottom, $0.03 \mathrm{mg} / \mathrm{l}$ being in December/97 and January/98 in ZI, and 0.07 $\mathrm{mg} / \mathrm{l}$ in November/97 in ZIR. The highest differences between surface and bottom $(8 \mathrm{mg} / \mathrm{l})$ were registered in November and December/97-98 and January/98-99 in ZI and (9 mg/l) in November/97 in ZIR. During that period the curve of DO distribution was clinograde-type.

Table 3 shows minimal, maximal, and average values and standard deviations of anions, cations, nitrogenous compounds, and orthophosphate for the study period.

Ionic concentrations at the different levels studied did not show marked differences, the water being characterized, according to ion prevalence, as bicarbonated, chlorinized, sodic, calcic and/or magnesic. Anion seasonal distribution in the limnetic zone revealed some differences in winter where the order changed into sulphated, bicarbonated and chlorinized.

Figure 4 shows the vertical profiles of temperature, $\mathrm{pH}$, conductivity, and dissolved oxygen 

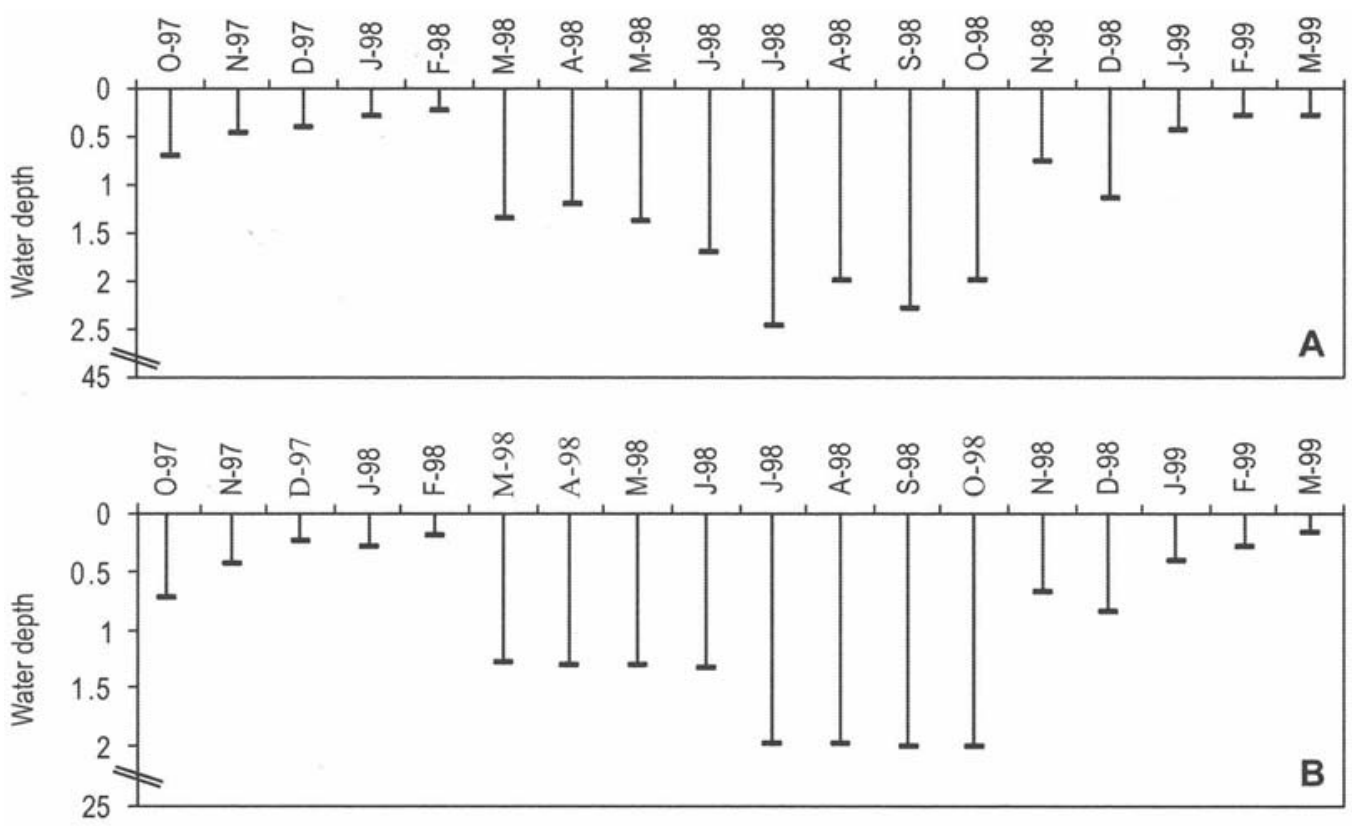

Figure 3. A-B. Transparency in the studied sites in the Dr. C. Gelsi reservoir. A-B Transparencia en los sitios estudiados del embalse Dr. C. Gelsi. A: ZI, B: ZIR.

for the limnetic zone (ZI) in December/97-98 and in June/98, these months being those that generally encompass time and space variations in such variables.

The rate of inorganic nitrogen in the sites studied was, in general, higher than $1 \mathrm{mg} / \mathrm{l}$, reaching $1.9 \mathrm{mg} / \mathrm{l}$ in May/98. Nitrate values were similar at the different depths considered, with the exception of what had happened in the hypolimnion in January and February 1998 and January/99 where a marked decrease was observed. Nitrite maximal records reached 0.5 and $0.2 \mathrm{mg} / \mathrm{l}$ in $\mathrm{ZI}$ in February/99 (on the surface) and in ZIR in February/98 (at the bottom), respectively, corresponding to the reservoir stratification period, and reaching values of $<0.01 \mathrm{mg} / \mathrm{l}$ during the mixing period. Ammonium showed a remarkable time and space fluctuation in ZI ranging between nondetectable and $0.09 \mathrm{mg} / \mathrm{l}$ at a depth of $10 \mathrm{~m}$ in February/98. In the case of ZIR, maximal variations occurred in spring 1997 and summer 1998 reaching $0.1 \mathrm{mg} / \mathrm{l}$ in February/98 (at the bottom) and then generally maintaining below $0.05 \mathrm{mg} / \mathrm{l}$.

Orthophosphate concentrations reached maximal values in $\mathrm{ZI}$ in October/97 in the hy- polimnion reaching $15.6 \mathrm{mg} / \mathrm{l}$. This value was 80 times higher with respect to the other depths. In general the average values of the studied monthly profiles in both sites were not higher than $0.2 \mathrm{mg} / \mathrm{l}$, moreover, orthophosphates were no detected in some samples. The orthophosphates did not have any correlation with the studied parameters in ZI, however this anion had highly significant negative correlations with some parameters in ZIR (Table 2).

Nitrogen and phosphorus concentrations in the water show approximately the same relative ratios found in living matter, where a 14-16:1 ratio in atoms is kept (Margalef, 1983). This ratio only coincided in $13 \%$ and $17 \%$ of the samples in ZI and ZIR, respectively. The relation was higher in $45 \%$ of the samples reaching 211 on the surface of ZI in October/98 due to the nearly total absence of soluble orthophosphate and with no ratio in non-detected cases. Tables 1 and 2 showed the highly significant and significant correlations obtained for the nitrate:orthophosphate ratio ( $\mathrm{N}: \mathrm{P}$ ratio).

Average values for silica dioxide concentrations in both zones were higher in the summer 
Temperature (Temp, $\left.{ }^{\circ} \mathrm{C}\right)$; Dissolved oxygen (Oxyg, mg/l); pH

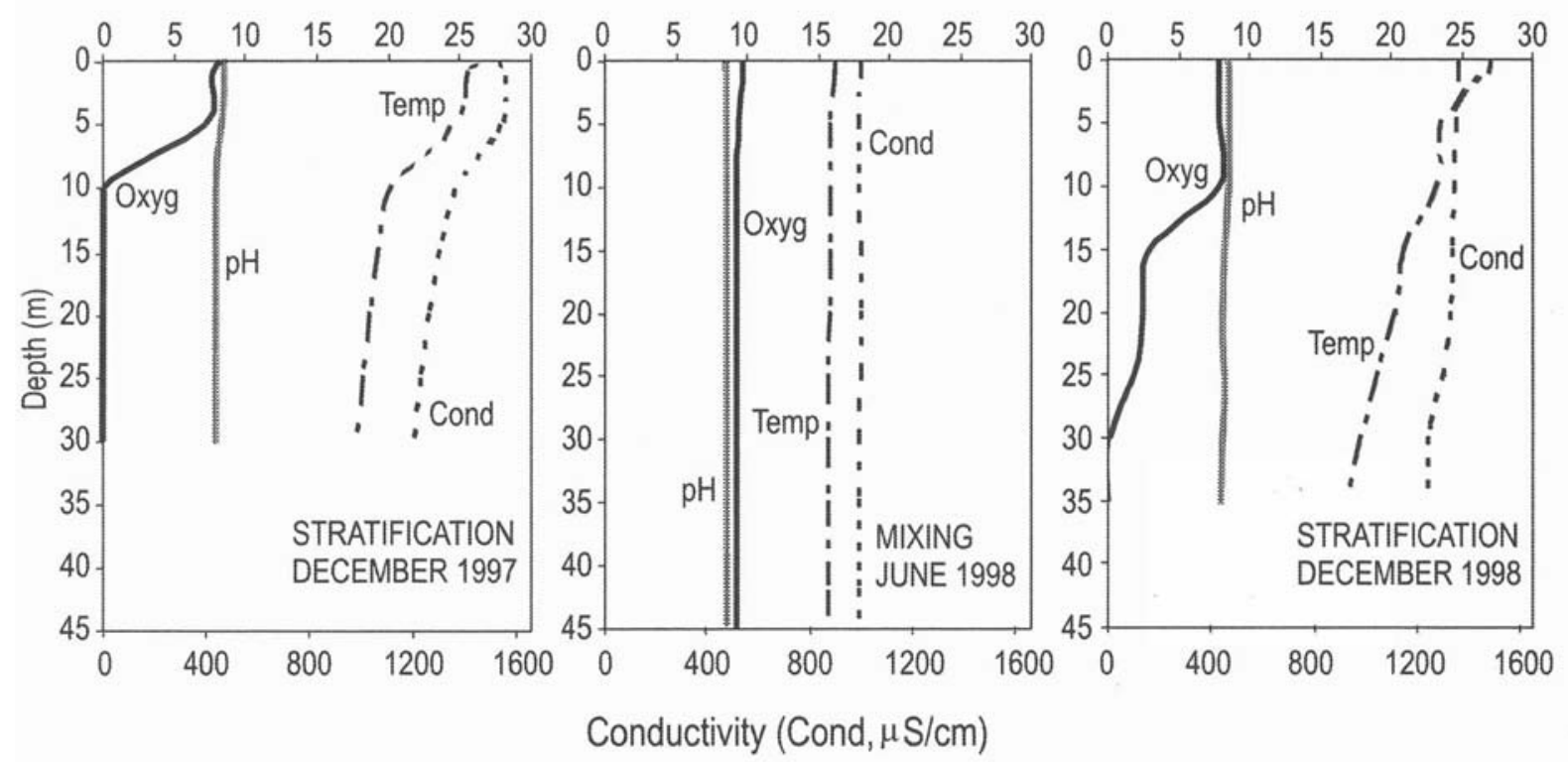

Figure 4. Behavior of temperature, $\mathrm{pH}, \mathrm{DO}$, and conductivity in the limnetic zone of the Dr. C. Gelsi reservoir in the mixing and stratification periods. Comportamiento de la temperatura, $\mathrm{pH}$, OD y conductividad eléctrica en la zona limnética en los períodos de mezcla y estratificación del embalse Dr. C. Gelsi.

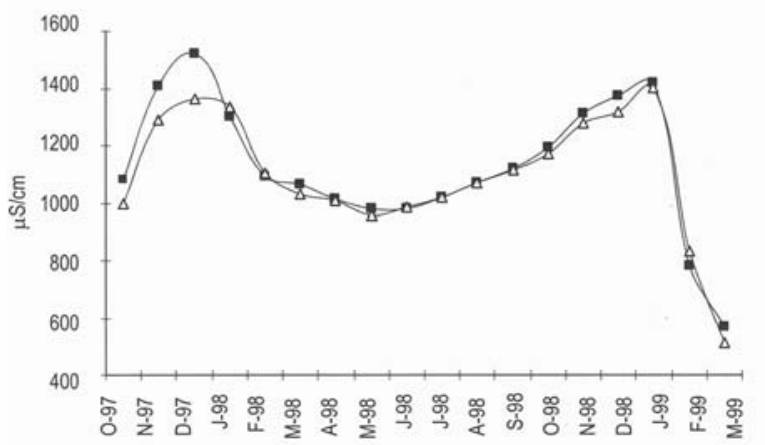

Figure 5. Conductivity average changes through the time in the water column for the limnetic and tributary intersection zones (ZI: white triangle and ZIR: black square symbols). Evolución en el tiempo del valor promedio de la conductividad en la columna de agua para la zona limnética y la zona de intersección de los tributarios (símbolos: triángulo blanco ZI y cuadrado negro ZIR).

of 1998, they decreased until the end of winter, and after their spring recovery they decreased reaching the lowest values in January 1999. The $\mathrm{Si}: \mathrm{P}$ ratio in about 70 of the samples was larger than 200 and ranged between 100 and 200 the remainder samples except in October/98 that it was 2 at the bottom of ZI. The highest ratios occurred during the mixing period, and in OctoberNovember/98 and January/99.

Total manganese was higher at the bottom than on the surface in both zones for the two stratification periods studied. In the first one, maximal values reached 0.7 and $0.6 \mathrm{mg} / \mathrm{l}$ in January/98 in ZI and ZIR, respectively, whereas in the second one they were $0.2 \mathrm{mg} / \mathrm{l}$ in October/98 in ZI, and $0.3 \mathrm{mg} / \mathrm{l}$ in February/99 in ZIR. Over the circulation period, manganese was not detected along the whole water column. Highly significant negative correlations with dissolved oxygen in both zones (Tables 1 and 2) were found.

Out of the eleven organochlorine pesticides studied, DDT and dieldrin isolated values were observed for ZIR, whereas practically throughout the whole period the presence of lindane and methoxychlor with higher values in warm months was detected. The highest average values for the two last ones in the first half of the year (April-September 1998) were 0.05 and 0.02 $\mu \mathrm{g} / \mathrm{l}$, respectively, whereas from September/98 to 
March/99 average values increased to 0.39 and $0.18 \mu \mathrm{g} / \mathrm{l}$. A similar seasonal behavior was observed in ZI, but the maximal values reached were lower than in ZIR with average values of 0.21 and $0.19 \mu \mathrm{g} / \mathrm{l}$ for lindane and methoxychlor, respectively, during the second summer period.

The organic matter values ranged from 1.47 $\%$ in November/98 to $1.54 \%$ in February/98 in ZI, whereas in ZIR they varied between $1.49 \%$ and $1.50 \%$ in every sediment sample studied.

The maximal value for total coliforms in both sampling sites was four logarithmic units in $\mathrm{Fe}$ bruary/98. Fecal streptococci figures reached 8 and $9 \mathrm{UFC} / 100 \mathrm{ml}$ in October/97 and May/98 in ZI, whereas in ZIR they only reached 8 UFC/100 $\mathrm{ml}$ in November/97.

The number of actinomycetes colonies ranged between 3 in April/98 and 272 in October/98 in ZI, whereas in ZIR it ranged between 8 and 94 in December 1997 and 1998, respectively, a negative correlation with dissolved oxygen in ZI (Table 1), and a positive correlation with DO in ZIR (Table 2) was obtained among other parameters.

The species phytoplankton richness (Table 4) in ZI was represented by 50 species: 26 Chlo-
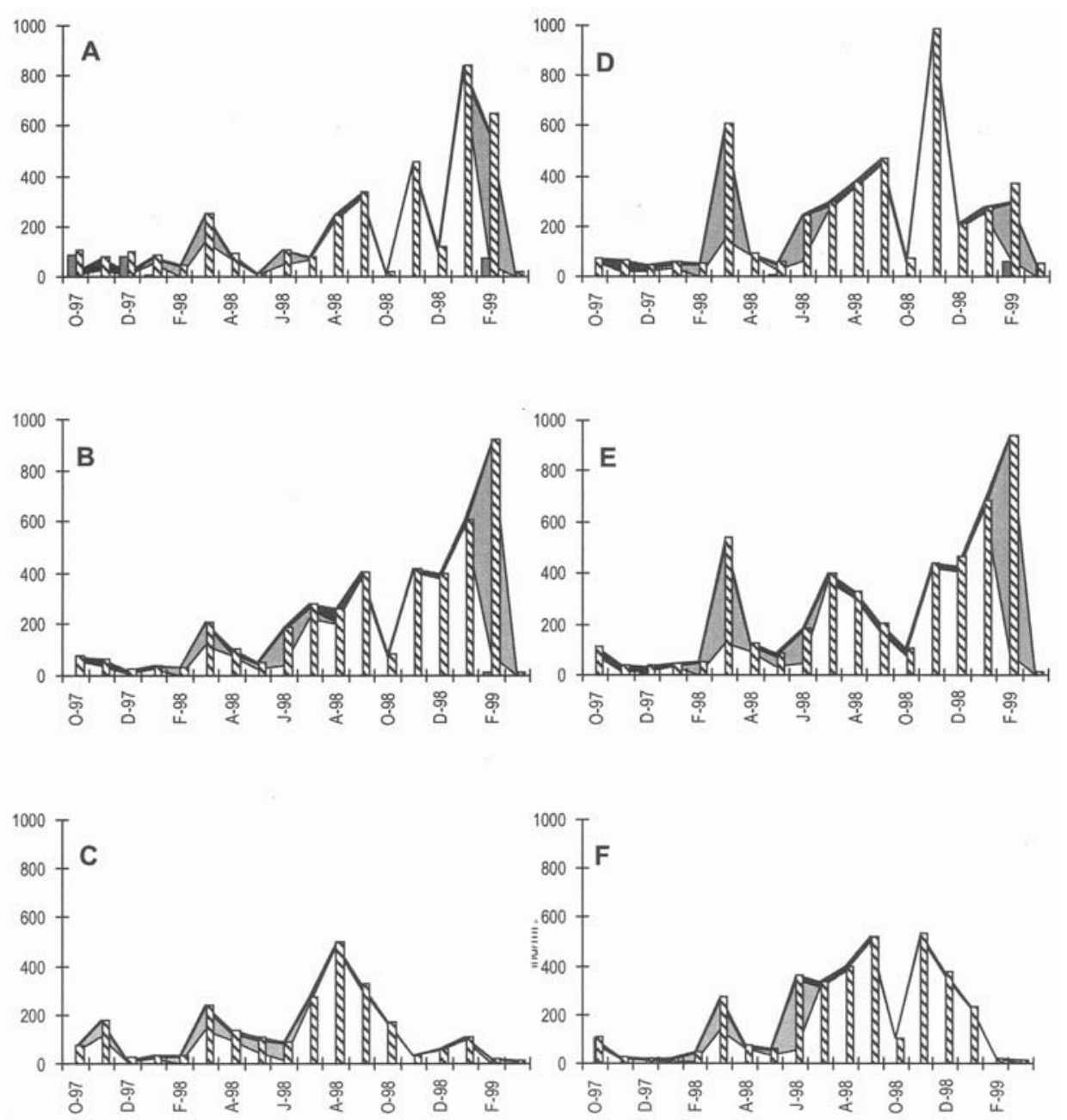

Figure 6. A-F. Variations of the main algal groups and total density of the Dr. C. Gelsi reservoir. A-C. In the limnetic zone: A. surface, B. 10 m, C. bottom, D-F. intersection zone of tributaries, D. surface, E. 5 m, F. bottom. A-F. Variaciones de los principales grupos algales y la densidad total del embalse Dr. C. Gelsi. A-C. en la zona limnética: A. superficie, B. 10 metros, C. fondo. D-F. zona de intersección de los ríos. D. superficie, E. 5 metros, F. fondo. 
Table 4. Algae species list from the Dr. C. Gelsi reservoir for ZI and ZIR. Lista de las especies algales del embalse Dr. C. Gelsi en ZI y ZIR.

\begin{tabular}{|c|c|c|}
\hline Especies & $\mathbf{Z I}$ & ZIR \\
\hline \multicolumn{3}{|l|}{ Cyanophyta } \\
\hline \multicolumn{3}{|l|}{ Cyanophyceae } \\
\hline Anabaena flos-aquae & $\mathrm{x}$ & $\mathrm{x}$ \\
\hline Lyngbya pristleyi & $\mathrm{X}$ & \\
\hline Merismopedia sp. & $\mathrm{x}$ & \\
\hline Microcystis aeruginosa & $\mathrm{X}$ & $\mathrm{x}$ \\
\hline Pseudanabaena mucicola & $\mathrm{X}$ & $\mathrm{X}$ \\
\hline \multicolumn{3}{|l|}{ Chlorophyta } \\
\hline Botryococcus braunii & $\mathrm{x}$ & $\mathrm{X}$ \\
\hline Chlamydomonas globosa & $\mathrm{x}$ & $\mathrm{x}$ \\
\hline Closterium aciculare & $\mathrm{x}$ & $\mathrm{x}$ \\
\hline Cl. acutum var. variabile & $\mathrm{x}$ & $\mathrm{x}$ \\
\hline Cl. venus & $\mathrm{x}$ & $\mathrm{x}$ \\
\hline Coelastrum cambricum & $\mathrm{x}$ & $\mathrm{x}$ \\
\hline C. microporum & $\mathrm{x}$ & $\mathrm{x}$ \\
\hline Cosmarium sp. & & $\mathrm{X}$ \\
\hline Monoraphidium pusillum & $\mathrm{x}$ & $\mathrm{x}$ \\
\hline Oocystis solitaria & $\mathrm{x}$ & $\mathrm{x}$ \\
\hline O. marsonii & $\mathrm{x}$ & $\mathrm{x}$ \\
\hline Pandorina morum & $\mathrm{x}$ & $\mathrm{x}$ \\
\hline Pediastrum boryanum var. brevicorne & & $\mathrm{x}$ \\
\hline P. duplex var. punctatum & $\mathrm{x}$ & $\mathrm{x}$ \\
\hline P. simplex & $\mathrm{x}$ & \\
\hline P. tetras & & $\mathrm{x}$ \\
\hline P. sp. 1 & $\mathrm{x}$ & \\
\hline P. sp.2 & $\mathrm{x}$ & \\
\hline Penium sp. & $\mathrm{x}$ & \\
\hline Planktosphaeria gelatinosa & $\mathrm{x}$ & $\mathrm{X}$ \\
\hline Scenedesmus acuminatus & $\mathrm{x}$ & $\mathrm{X}$ \\
\hline S. acutus & $\mathrm{x}$ & $\mathrm{x}$ \\
\hline S. acutus f. costulatus & $\mathrm{x}$ & $\mathrm{x}$ \\
\hline S. arcuatus & $\mathrm{x}$ & \\
\hline S. ecornis & $\mathrm{x}$ & \\
\hline S. quadricauda & $\mathrm{x}$ & $\mathrm{x}$ \\
\hline$S$. sp. & $\mathrm{x}$ & \\
\hline Sphaerocystis schroeterii & $\mathrm{x}$ & $\mathrm{x}$ \\
\hline Staurastrum sp. & $\mathrm{x}$ & $\mathrm{x}$ \\
\hline
\end{tabular}

rophyta, 17 Bacillariophyceae, 5 Cyanophyceae, and 2 Dinophyceae, whereas in ZIR it was represented by 49 taxa: 22 Chlorophyta, 21 Bacillariophyceae, 3 Cyanophyceae, and 3 Dinophyceae. Fifty-seven taxa were registered in total: $49 \%$ green algae, $37 \%$ diatoms, $9 \%$ Cyanobacteria, and $5 \%$ dinoflagelates. The highest number of algal entities were 19 species registered on the surface (January/99 in ZI and ZIR) and at a depth of $10 \mathrm{~m}$ (February/99 in ZI). Species richness generally decreased with depth.

The list of major phytoplankton species and the saprobic grades obtained for every taxon is shown in Table 5. The phytoplankton was dominated by diatoms and, in a lesser degree, by the other algal groups (Fig. 6 A-F). Aulacoseira granulata stood out spatially and temporarilly throughout the annual cycle and it was surpassed only in five occasions by Cyclotella meneghiniana, that is, in February 1998 and 1999, June/98 and March/99, and in March/98 in ZIR. The proliferation of A. granulata and C. meneghiniana registered maximal values of $806 \mathrm{ind} / \mathrm{ml}$ in ZI (January/99, on the surface) and $824 \mathrm{ind} / \mathrm{ml}$ (February/99, at a depth of 10 $\mathrm{m})$, respectively. In ZIR they reached $968 \mathrm{ind} / \mathrm{ml}$ (November/98, on the surface) for A. granulata and $843 \mathrm{ind} / \mathrm{ml}$ (February/99, at a depth of $5 \mathrm{~m}$ ) for $C$. meneghiniana. In both surface samples Anabaena flos-aquae in October and December 1997 stood out, as did Botryococcus braunii in October/98 in ZI, and in both zones Closterium acutum var. variabile in November/97 was the most noticeable one.

In some months phytoplankton density did not reach the maximal values on the surface. It
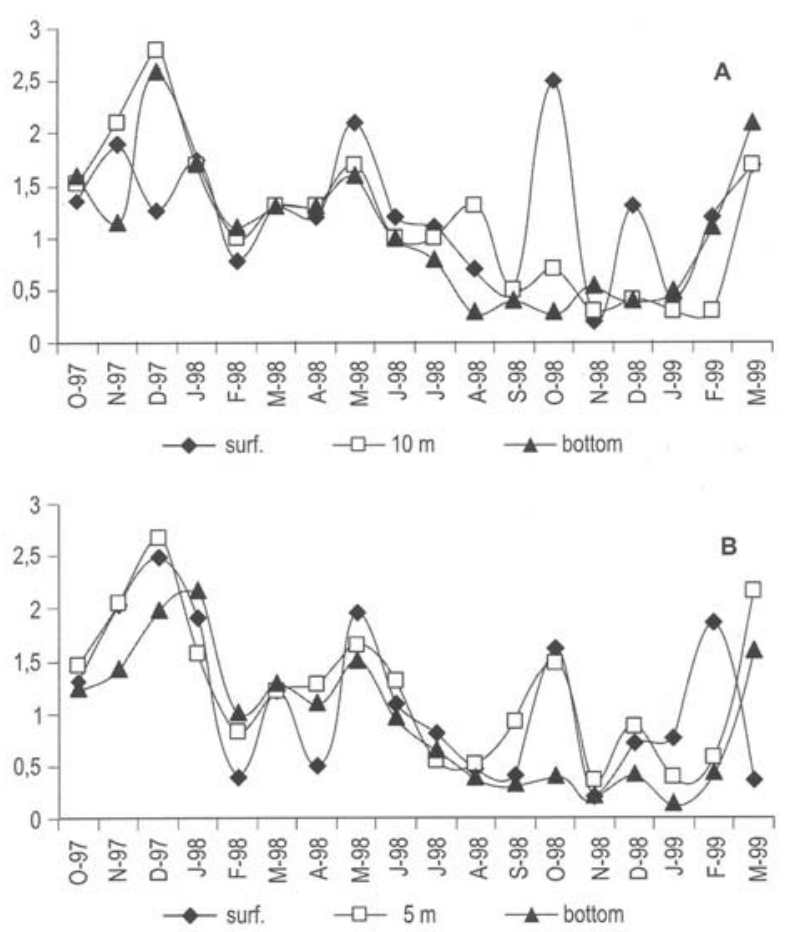

Figure 7. A-B. Profile variations of specific diversity, A. limnetic zone, B. intersection zone of tributaries. A-B. Variaciones de la diversidad específica en los perfiles, $A$. zona limnética; $B$. zona de integración de los afluentes. 

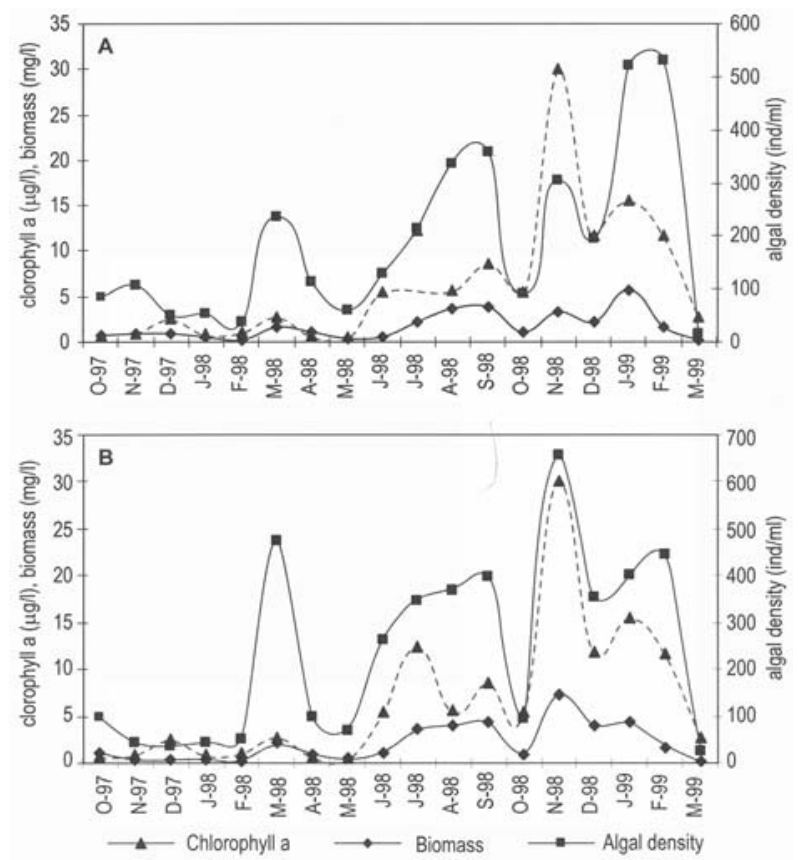

Figure 8. A-B. Average values of chlorophyll $a$, phytoplankton biomass and density in the Dr. C. Gelsi reservoir. A. limnetic zone; B. intersection zone of tributaries. A-B. Valores promedios de clorofila a, biomasa y densidad del fitoplancton del embalse Dr. C. Gelsi: A. zona limnética (ZI); B. zona de intersección de los tributarios (ZIR).

was higher in the deep in April, May, August and October/98 in ZI; it was similar only in October/98 in ZIR.

Species diversity (Fig. $7 \mathrm{~A}$ and $\mathrm{B}$ ) ranged between 0.2 (November/98, on the surface) and 2.8 (December/97, at a depth of $10 \mathrm{~m}$ ) in ZI, while in ZIR it ranged between 0.1 (January/99, at the bottom) and 2.7 (December/97, at a depth of $5 \mathrm{~m}$ ). This index showed low values in winter and in November-December/98 and January/99 (summer) due to a marked growth of $A$. granulata and $C$. meneghiniana.

Figure 8 (A-B) represents the average values of algal density, biomass, and chlorophyll a both in ZI and ZIR. The number of average individuals/ml in the water column ranged between 16 (March/99) and 531 (February/99) in ZI, whereas in ZIR it ranged between 27 (March/99) and 655 (November/98). The highest average biomass values on the vertical profile for both sam- pling sites occurred in July-September/98 and in November/98-January/99. These records ranged between 2.15 and $7.4 \mathrm{mg} / \mathrm{l}$, while in the other months they did not exceed $1.7 \mathrm{mg} / \mathrm{l}$. The biomass values in both sites, increased in the deep in the same months as the phytoplankton density. The highest difference among the three levels appeared in ZI during the 98-99 summer stratification, being higher in January with values of 9.2, 6.7 and $1.2 \mathrm{mg} / \mathrm{l}$ on the surface, at a depth of $10 \mathrm{~m}$ and at the bottom, respectively.

The biomass percentage in ZI corresponding to the surface was $64 \%$ for diatoms, $22 \%$ for green algae, $13 \%$ for cyanobacteria, and $1 \%$ for dinoflagelates. Cyanobacteria only prevailed in October and December/97, and were subdo-

Table 5. List of the most abundant species and their saprobic grades obtained for the Dr. Gelsi reservoir. 1: oligo$\beta$-mesosaprobic (s: 1.5); 2: $\beta$ - $\alpha$-mesosaprobic (s: 2.5), 3: $\alpha$ mesosaprobic (s: 3). ${ }^{(*)}$ The eleven species coincide with those for the 1988-1989 period. Lista de especies mayoritarias y sus grados sapróbicos obtenidos para el embalse Dr. C. Gelsi. 1: oligo- $\beta$-mesosaprobias (s: 1.5), 2: $\beta$ - $\alpha$-mesosaprobias (s: 2.5 ), 3: $\alpha$-mesosaprobias (s: 3). $\left.{ }^{*}\right)$ Las once especies son coincidentes con las del período 1988-1989.

\begin{tabular}{|c|c|c|c|}
\hline & 1 & 2 & 3 \\
\hline \multicolumn{4}{|l|}{ Cyanophyta } \\
\hline \multicolumn{4}{|l|}{ Cyanophyceae } \\
\hline$\left(^{*}\right)$ Anabaena flos-aquae (Lyngbye) Brébisson & & & $\mathrm{x}$ \\
\hline 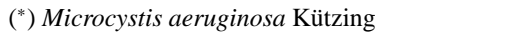 & & & $\mathrm{x}$ \\
\hline \multicolumn{4}{|l|}{ Chlorophyta } \\
\hline (*)Botryococcus braunii Kützing & $\mathrm{x}$ & & \\
\hline Closterium aciculare West & $\mathrm{x}$ & & \\
\hline \multicolumn{4}{|l|}{$\left(^{*}\right)$ Closterium acutum var. variabile } \\
\hline$\left({ }^{*}\right)$ Closterium venus Kützing & & $\begin{array}{l}x \\
x\end{array}$ & \\
\hline (*) Coelastrum microporum Naegeli & & & $\mathrm{x}$ \\
\hline 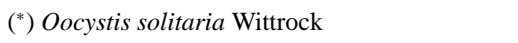 & & & $\mathrm{x}$ \\
\hline Oocystis marsonii Lemmermann & & & $\mathrm{x}$ \\
\hline 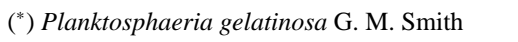 & $\mathrm{x}$ & & \\
\hline 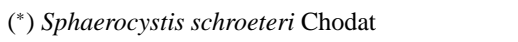 & & & $\mathrm{x}$ \\
\hline Staurastrum sp. & & & $\mathrm{x}$ \\
\hline \multicolumn{4}{|l|}{ Dinophyta } \\
\hline \multicolumn{4}{|l|}{ Dinophyceae } \\
\hline \multicolumn{4}{|l|}{ Glochidinium penardiforme (Lindemann) } \\
\hline Boltovskoy & & $\mathrm{x}$ & \\
\hline Peridinium volzii Lemmermann & & $\mathrm{x}$ & \\
\hline Peridinium willei Huitfeld-Kaas & & $\mathrm{x}$ & \\
\hline \multicolumn{4}{|l|}{ Heterokontophyta } \\
\hline \multicolumn{4}{|l|}{ Bacillariophyceae } \\
\hline$\left(^{*}\right)$ Aulacoseira granulata (Ehrenberg) Simonsen & & & $\mathrm{x}$ \\
\hline (*) Cyclotella meneghiniana Kützing & & $\mathrm{x}$ & \\
\hline
\end{tabular}



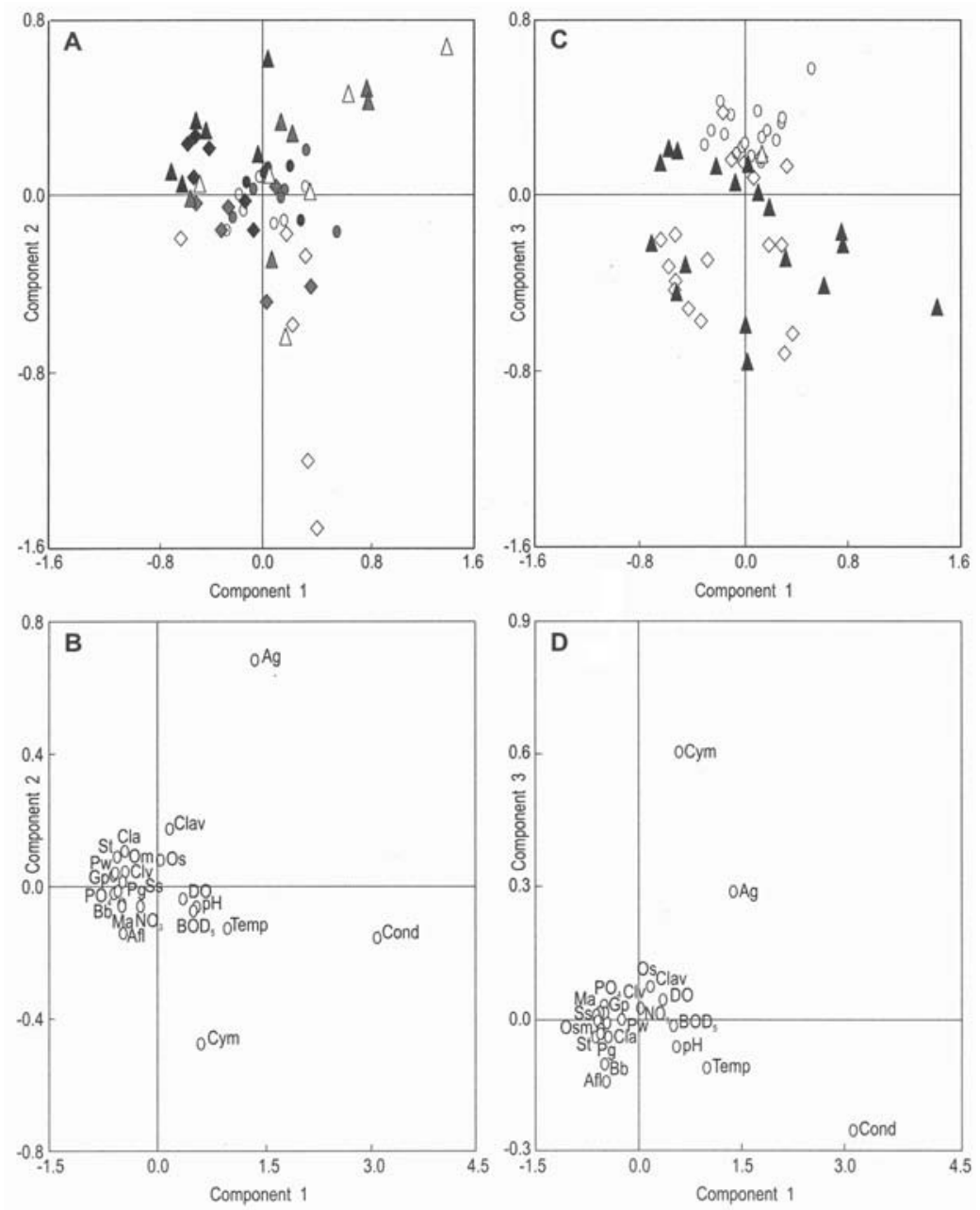

Figure 9. A-D. Principal Components Analysis (PCA) of the limnetic zone of the Dr. C. Gelsi reservoir in relation to phytoplankton density and some physical and chemical variables. A-B: graphic representation of Components 1 and 2; C-D. Graphic representation of Axes 1 and 3. Abbreviations used for species are: Anabaena flos-aquae (Afl), Aulacoseira granulata (Ag), Botryococcus braunii (Bb), Closterium aciculare (Cla), Closterium acutum var. variabile (Clav), Closterium venus (Clv), Cyclotella meneghiniana (Cym), Glochidinium penardiforme (Gp), Microcystis aeruginosa (Ma), Oocystis marsonii (Om), Oocystis solitaria (Os), Peridinium willei $(\mathrm{Pw})$, Planktosphaeria gelatinosa (Pg), Sphaerocystis schroeteri (Ss), and Staurastrum sp. (St); abbreviations used for physical and chemical variables are: conductivity (Cond), biological oxygen demand $\left(\mathrm{BOD}_{5}\right)$, nitrate $\left(\mathrm{NO}_{3}^{-}\right)$, orthophosphate $\left(\mathrm{PO}_{4}\right)$, dissolved oxygen (DO), hydrogen potential $(\mathrm{pH})$, and temperature (Temp); symbols for the periods studied Fig. 9 A are: October/97March/98 stratification (rhombi: white, surface; gray, 10 meters, and black, bottom), April/98-September/98 mixture (ellipses: white, surface; gray, 10 meters, and black, bottom), October/98-March/99 stratification (triangles: white, surface; gray 10 meters, and black, bottom); Fig. 9 C: October/97-March/98 stratification (rhombi white), April/98-September/98 mixture (ellipses white), and October/98-March/99 stratification (triangles black). A-D. Análisis de componentes principales (ACP) de la zona de limnética (ZI) del embalse Dr. C. Gelsi en relación con la densidad del fitoplancton y algunas variables físicas y químicas: A-B. Representación de los Componentes 1 y 2; C-D. Representación de los Ejes 1 y 3. Las abreviaturas usadas para las especies son: Anabaena flosaquae $(A f)$, Aulacoseira granulata $(A g)$, Botryococcus braunii $(B b)$, Closterium aciculare $(C l a)$, Closterium acutum var. variabile $(C l a v)$, Closterium venus $(C l v)$, Cyclotella meneghiniana $(C y m)$, Glochidinium penardiforme $(G p)$, Microcystis aeruginosa $(M a)$, Oocystis marsonii $(O m)$, Oocystis solitaria $(O s)$, Peridinium willei $(P w)$, Planktosphaeria gelatinosa $(P g)$, Sphaerocystis schroeteri (Ss), Staurastrum sp. (St); abreviaturas utilizadas para las variables físicas y químicas: conductividad eléctrica (Cond), demanda bioquímica de oxígeno $\left(\mathrm{DBO}_{5}\right)$, nitrato $\left(\mathrm{NO}_{3}^{-}\right)$, ortofosfato $\left(\mathrm{PO}_{4}\right)$, oxígeno disuelto $(\mathrm{OD})$, potencial hidrógeno $(\mathrm{pH})$, temperatura (Temp); símbolos de los períodos estudiados, Fig. 9 A: estratificación octubre/97-marzo/98 (rombos: blanco, superficie; gris, 10 metros y negro, fondo), mezcla abril/98-setiembre/97 (elipses: blanca, superficie; gris, 10 metros y negra, fondo), estratificación octubre/98-marzo/99 (triángulos: blanco, superficie; gris, 10 metros y negro, fondo); Fig. 9 C: estratificación octubre/97-marzo/98 (rombos blancos), mezcla abril/98-setiembre/97 (elipses blancas), estratificación octubre/98-marzo/99 (triángulos negros). 
minant in January, February, and October 1998 and February 1999.Chlorophyta prevailed in May and October 1998 and March/99. In ZIR, also on the surface, the biomass percentage was $78 \%$ for diatoms, $16 \%$ for green algae, $5 \%$ for cyanobacteria, and $1 \%$ for dinoflagelates. Bacillariophyceae were dominant except in November and December 1997 when Chlorophyta prevailed. Cyanobacteria were subdominant in February and May 1998 and February 1999. At other levels diatoms stood out and they were seldom surpassed by green algae.

Concentrations of chlorophyll $a$ revealed a decrease with depth in most of the period studied in both zones, their average values increased from winter to summer 1999. Both in ZI and ZIR, hypolimnion concentrations were detected lower than $1.2 \mu \mathrm{g} / \mathrm{l}$ from October 1997 to May 1998. Maximal values were obtained on the surface with $63 \mu \mathrm{g} / 1$ for ZI in February 1999, whereas in ZIR they were $35 \mu \mathrm{g} / 1$ in November 1998. The obtained correlations for the chlorophyll are showed in Tables 1 and 2.

It is important to notice that the results of phytoplankton density and chlorophyll $a$ at depth come from a wide range of values obtained. This could be the reason that a positive correlation between these two parameters was gotten, even if reduction in the phytoplankton density was only detected in some months.

The saprobic index that ranged between 2.5 and 3 , characterized the reservoir water quality as $\beta$ - $\alpha$-mesosaprobic with records of biochemical oxygen demand lower than $7 \mathrm{mg} / \mathrm{l}$ to $\alpha$ mesosaprobic with $\mathrm{BOD}_{5}$ values lower than 13 $\mathrm{mg} / \mathrm{l}$. In some samples, the saprobic index did not agree with the organic matter, thus in $\mathrm{ZI}$ in December 1997 waters were $b$-mesosaprobic with $\mathrm{BOD}_{5}$ values of $11 \mathrm{mg} / \mathrm{l}$, whereas in June 1998 and September 1998 they were $\alpha$-mesosaprobic with $\mathrm{BOD}_{5}$ rate of 17 to $19 \mathrm{mg} / \mathrm{l}$.

In the PCA for ZI, the first four components accounted for $58 \%$ of data variability, the first three axes being responsible for $18 \%, 15 \%$, and $13 \%$ of the total variance. Component 1 ordinated towards the negative portion such as the bottom samples for both stratification periods, and those of the first months of the mixing period
(Fig. 9 A). Abiotic variables of axis 1 that contributed to this ordination were $\mathrm{pH}$, dissolved oxygen, nitrate, and conductivity (intra-set correlation coefficients: $0.71 ; 0.46 ;-0.46$, and 0.42 , respectively). The algae that accounted for most of the distribution of the samples were $C$. acutum var. variabile, A. granulata, Glochidinium penardiforme, and Staurastrum sp. (intra-set correlation coefficients: $0.69 ; 0.68 ; 0.59$ and 0.55 , respectively) (Fig. $9 \mathrm{~B}$ ).

With regards to component 2 , it revealed a significant correlation with a few environmental variables and separated the '97-'98 stratification towards the negative portion, and that of '98-'99 period towards the positive one. Mixing months were arranged between the previously mentioned periods (Fig. 9 A). The algae that most contributed to the arrangement regarding component 2 were Anabaena flos-aquae, Planktosphaeria gelatinosa and Sphaerocystis schroeteri (intra-set correlation coefficients: $-0.80,-0.73$, and -0.64 , respectively) (Fig. $9 \mathrm{~B}$ ).

Component 3 arranged the samples of the mixing period towards the positive quadrant and those of both stratifications were, in general, located negatively. The abiotic variables of axis 3 that contributed to the sample distribution were conductivity, temperature, dissolved oxygen, and nitrate (intra-set correlation coefficients: -0.55 ; $-0.54 ; 0.51 ; 0.40$, respectively). Prevalent algae were $B$. braunii and $C$. meneghiniana (intraset correlation coefficients: $-0.69 ; 0.46$, respectively) (Fig. $9 \mathrm{C}$ and $\mathrm{D}$ ).

In the PCA for ZIR, the first four components were found to account for $55 \%$ of data variability, the first three axes being responsible for $21 \%, 12 \%$, and $11 \%$ of the total variance. In figure $10 \mathrm{~A}$, in relation to components 1 and 2, it was observed how variables arranged most months of the '98-'99 stratification period on the surface and at a depth of $5 \mathrm{~m}$ towards the upper quadrants, and towards the lower quadrants those of the mixing period and those of some months of the '97-'98 stratification. The remaining samples of the latter period were found spread in the positive sector of component 2 and those at the bottom of those stratifications were located in the negative portion 

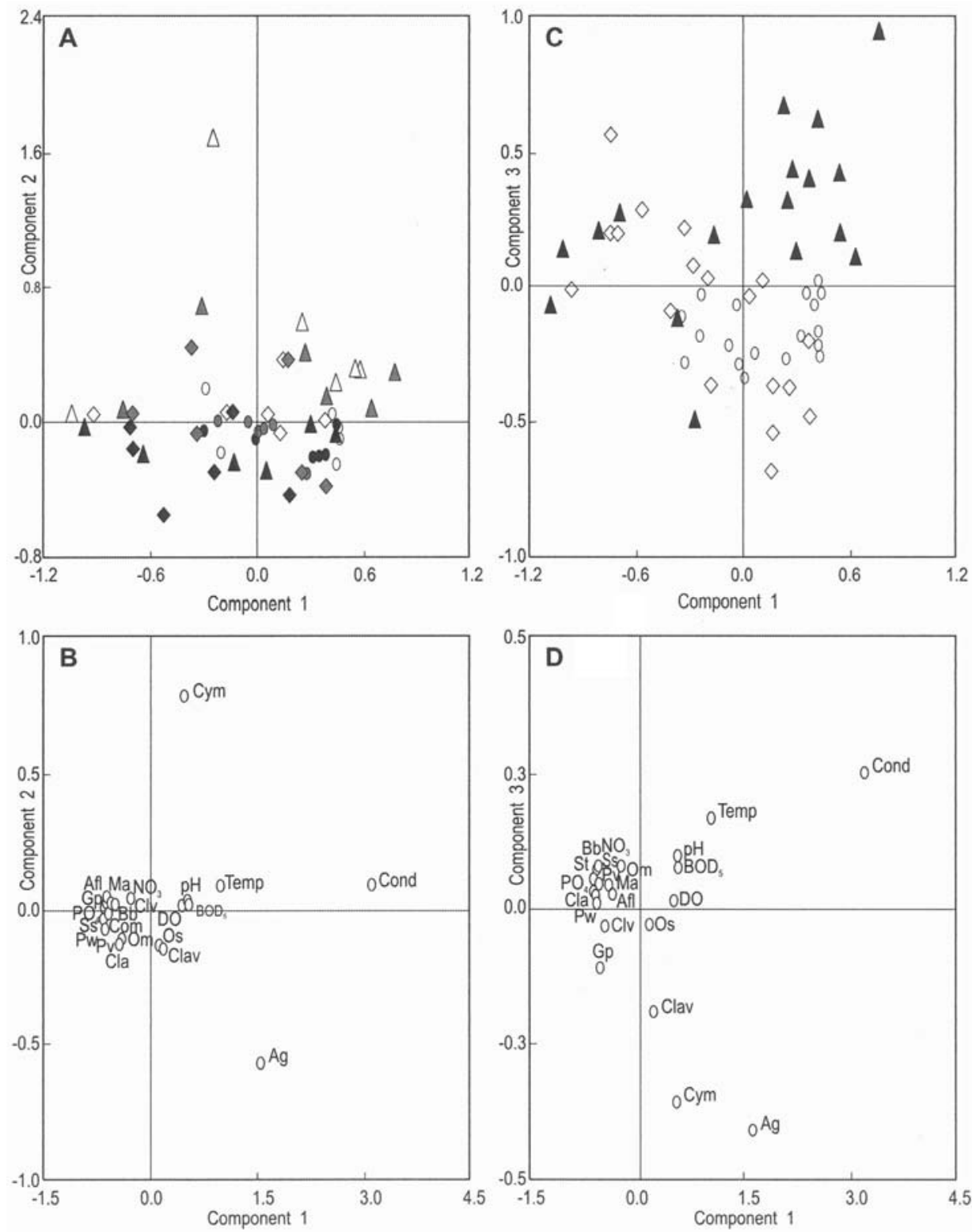

Figure 10. A-D. Principal Components Analysis (PCA) of the tributaries intersection zone of the Dr. C. Gelsi reservoir in relation to phytoplankton density and some physical and chemical variables: A-B. Graphic representation of Components 1 and 2; C-D. Graphic representation of Axes 1 and 3. The abbreviations used for species and physical and chemical variables are the same as in figure 9. Symbols for the studied periods Fig. 10 A: October/97-March/98 (rhombi: white, surface; gray, 5 meters, and black, bottom), April/98-September/98 mixing period (ellipses: white, surface; gray, 5 meters, and black, bottom), October/98-March/99 stratification period (triangles: white, surface; gray, 5 meters, and black, bottom); Fig. 10 C: October/97-March/98 stratification (rhombi white), April/98-September/98 mixture (ellipses white), October/98-March/99 stratification (triangles black). A-D. Análisis de componentes principales $(A C P)$ de la zona de integración de los afluentes (ZIR) del embalse Dr. C. Gelsi en relación con la densidad del fitoplancton y algunas variables físicas y químicas: A-B. Representación de los Componentes 1 y 2; C-D. Representación de los Ejes 1 y 3. Las abreviaturas usadas para las especies y las variables físicas y químicas son las mismas que en la figura 9. Símbolos de los períodos estudiados Fig. 10 A: estratificación octubre/97-marzo/98 (rombos: blanco, superficie; gris, 5 metros y negro, fondo), mezcla abril 98-setiembre/97 (elipses: blanca, superficie; gris, 5 metros y negra, fondo), estratificación octubre/98marzo/99 (triángulos: blanco, superficie; gris, 5 metros y negro, fondo); Fig. 10 C: estratificación octubre/97-marzo/98 (rombos blancos), mezcla abril/98-setiembre/97 (elipses blancas), estratificación octubre/98-marzo/99 (triángulos negros). 
of component 2. The abiotic parameters of component 1 that contributed to this arrangement were $\mathrm{pH}$, orthophosphate, nitrate, conductivity, and DO (intra-set correlation coefficients: 0.76, $-0.75,-0.58,0.50$, and 0.40 , respectively). Those of component 2 were temperature (intra-set correlation coefficients: 0.47), whereas the algae that most contributed, either due to their density or to their space correlation in the distribution of samples were in the first component A. granulata, Oocystis solitaria, and C. acutum var. variabile (intra-set correlation coefficients: $0.88,0.80$ and 0.62 , respectively), and in component 2 Microcystis aeruginosa, Anabaena flos-aquae, and $G$. penardiforme (intra-set correlation coefficients: $0.68,0.65$, and 0.63 , respectively) (Fig. $10 \mathrm{~B}$ ). Component 3 (Figs. $10 \mathrm{C}$ and D) exhibited a low correlation with environmental variables, whereas the algae that contributed to sample distribution were Closterium venus, C. meneghiniana, and Peridinium volzii (intra-set correlation coefficients: $-0.65,-0.55$ and 0.53 , respectively).

\section{DISCUSSION AND CONCLUSIONS}

Marked variations of hydrological behavior throughout the 18 months studied determined minimal volumes in spring and maximal volumes in summer-autumn. The delay of the rainy summer period in the '97-'98 period resulted in low water levels (Fig. 2) coincident with those of the 1987' 88 period (Tracanna et al., 1991).

Low values for transparency are mainly due to the turbidity caused by the increase of suspended solids in rainy periods in accordance with what was observed by Ferrer et al., 2000, among other authors, that assert that the low transparency registered for a reservoir should not always be attributed to the development of algal communities.

From a thermal viewpoint the reservoir was characterized as a warm monomictic-type lake, that is, it shows only one relatively long annual circulation period (April-September) with temperatures always higher than $4{ }^{\circ} \mathrm{C}$, a category which most northern and central
Argentine reservoirs belong to (Locascio et al., 1997, among others).

Waters are alkaline, a characteristic caused by the chemical composition of basin rocks that exhibit a prevalence of bicarbonate. From October to March $\mathrm{pH}$ records were higher on the surface than at the bottom.

Conductivity reached high values in relation with other studies conducted in Argentine reservoirs (Arjona et al., 2000, Bonetto et al., 1976, among others).

Conductivity measurement allows for the approximate assessment of global water mineralization. According to general average values of conductivity, and taking into account the French Regulation (Rodier, 1990) that estimates the ratio between mineralization and conductivity, the waters were classified as ones with excessive mineralization since they exceed $1100 \mu \mathrm{S} / \mathrm{cm}$. In the 1987 -' 89 period the waters were significantly mineralized because the conductivity did not exceeded $900 \mu \mathrm{S} / \mathrm{cm}$ (Tracanna et al., 1991).

Dissolved oxygen determinations were about $0 \mathrm{mg} / \mathrm{l}$ in the deep from November to January coinciding with the reservoir heterothermy, they being homogeneous from March onwards in the whole water column.

According to ion prevalence, reservoir waters could be characterized as bicarbonated (26\%), chlorinized (23\%), sodic (23\%), calcic (5$3.8 \%$ ), and/or magnesic (4\%). Sometimes sulphate values surpassed those of bicarbonates by insignificant differences. Marked differences were not observed between ionic concentrations at the intersection river zone and the limnetic zone among the various levels considered. These results could indicate that the conductivity difference found is produced by water level and rains instead of ionic changes.

The decrease of nitrate in the bottom during the stratification period coincides with the increase of nitrite and ammonium. This result is a consequence of the anoxic conditions.

Nitrogen, phosphorus, and silica inorganic forms mainly behave as nutrients, and their evaluation is important for the interpretation of the organisms distribution and annual cycles. The same can be said for the assessment 
of the trophy grade of the water body and other phenomena related to its eutrophication (Lopretto \& Tell, 1995). High concentrations of phosphorus and nitrogen usually cause an increment in algal biomass, and phosphorus is considered to be the major limiting factor for their growth. Reynolds $(1980,1982)$ considered that nutrient level in lakes is one of the most important determinants in species changes, since some algal taxa tend to prevail in water bodies with a similar trophic level.

Nutrient annual cycle in temperate waters is generally winter-produced and spring-summerconsumed (Margalef, 1983). In lakes, levels of nitrate in excess of $0.2 \mathrm{mg} / \mathrm{l}$ of nitrate tend to stimulate algal growth and indicate possible eutrophic conditions (Chapman \& Kimstach, 1992). Our records generally exceeded this value.

The highest orthophosphate accumulations were generally included in both zones at deep levels coinciding with the release of deposited phosphorous in the anoxia periods (Margalef, op . cit.). In winter and spring, phosphorus consumption by phytoplankton populations caused a decrease of this element's concentration in the epilimnion (López et al., 1984).

Diatoms are, in general, good competitors owing to the presence of phosphorus, and they substitute other algal groups when $\mathrm{N}: \mathrm{P}$ and $\mathrm{Si}: \mathrm{P}$ ratios are high and temperatures low (Negro et al., 1994).
These conditions were observed in this reservoir except for the temperatures, and the N:P ratio average in both sites was higher than 16 (Table 3). Tilman et al. (1984) and Sánchez Castillo et al. (1989) among others, emphasized the importance of the $\mathrm{Si}: \mathrm{P}$ ratio in the structure determination of algal communities. Our results confirmed a phytoplankton dominated by diatoms with $\mathrm{Si}: \mathrm{P}$ ratios of up to 1742 . It is important to point out that the increase in the relation $\mathrm{Si}: \mathrm{P}$ was due to the significant diminution of the orthophosphate in Jannuary/99 and other months.

Manganese and iron, the most abundant metals in a group in which valence changes as a function of the redox potential, are very apparent. $\mathrm{Mn}$ in its reduced form is more soluble and, in general, the low redox potential zone invades deep waters and sediments in summer or towards the end of it, Mn being first solubilized (Margalef, 1983). This agreed with the high values of this metal detected at the bottom of the reservoir during the stratification periods.

The worldwide use of organochlorine pesticides is totally or partially restricted because they have toxic effects and long persistence periods in the environment (Arias Verdes et al., 1992). In our study methoxychlor and lindane were mainly detected in concentrations that did no exceed the tolerance limits of $30 \mu \mathrm{g} / \mathrm{l}$ for methoxychlor and $3 \mu \mathrm{g} / \mathrm{l}$ for lindane (Arias Verdes et al., op. cit.; De la Canal \& Asociados, 1994) and these values

Table 6. Comparison between maximal, minimal, and average values of specific richness, algal density, biomass, and chlorophyll $a$ registered in Dr. C. Gelsi reservoir in 1987/88 and those of this paper. Data with an asterisk were taken from Martínez De Marco $\&$ Tracanna, 2001. Abbreviations used correspond to: $\min .=$ minimum; $\max =$ maximum; $\mathrm{X}=$ average; sd= standard deviation. Comparación de los valores máximos, mínimos y promedios de riqueza específica, densidad algal, biomasa y clorofila a registrados en el embalse Dr. C. Gelsi durante 1987/88 y los del presente trabajo. Los datos con asterisco fueron tomados de Martínez De Marco \& Tracanna, 2001. Las abreviaturas utilizadas corresponden a: mín. = mínimo; máx. = máximo; $X=$ promedio; sd = desviación estándar.

\begin{tabular}{|c|c|c|c|c|c|c|c|c|c|c|c|c|}
\hline \multirow{3}{*}{$\begin{array}{l}\text { Variables } \\
\text { Specific richness }\end{array}$} & \multicolumn{4}{|c|}{ 1987-1988 } & \multicolumn{4}{|c|}{$\begin{array}{c}\text { 1997-1999 } \\
\text { (limnetic zone }(\mathrm{ZI}))\end{array}$} & \multicolumn{4}{|c|}{$\begin{array}{c}1997-1999 \\
\text { (river intersection zone (ZIR)) }\end{array}$} \\
\hline & \multicolumn{4}{|c|}{47 species } & \multicolumn{4}{|c|}{50 species } & \multicolumn{4}{|c|}{49 species } \\
\hline & $\min$. & $\max$ & $\mathrm{X}$ & sd & $\min$. & $\max$. & $\mathrm{X}$ & sd & $\min$. & $\max$. & $\mathrm{X}$ & sd \\
\hline Algal density (ind/ml) & $0.24 *$ & $582 *$ & 81 & 120.3 & 13 & 924 & 190 & 208.6 & 13 & 988 & 236 & 232.5 \\
\hline Specific diversity & $0.1^{*}$ & $2.6^{*}$ & 1.2 & 0.7 & 0.2 & 2.8 & 1.17 & 0.6 & 0.1 & 2.7 & 1.1 & 0.7 \\
\hline Biomass (mg/l) & $0.001^{*}$ & $4.3^{*}$ & $0.6^{*}$ & 0.8 & 0.06 & 9.24 & 1.7 & 1.9 & 0.08 & 11.1 & 2.1 & 2.2 \\
\hline Chlorophyll $a(\mu \mathrm{g} / \mathrm{l})$ & - & - & - & - & 0.03 & 63 & 6.4 & 10.7 & 0 & 35 & 6.7 & 8.4 \\
\hline
\end{tabular}


agreed with a study referring the presence of OP along the Salí river course (Chaile et al., 1999).

The values of bacterial load (total coliforms, faecal coliforms, and faecal streptococci) of ZI and ZIR were compatible with water quality standards (De la Canal \& Asociados, op. cit.), since values of only four logarithmic units in total coliforms in February 1998 were obtained.

Variations in the number of actinomycetes colonies in sediments were mainly conditioned by temperature and dissolved oxygen rather than by organic matter, since the latter remained unchanged along this study. However, in this study only the total actinomycetes colony numbers and not their taxonomy was determined, so the correlations in both sites were different with respect to the DO, possibly because of the adaptation of these bacteria to the environmental conditions by their sporulation capacity or the presence of different genus (Takizawa et al.,1993; Amoroso et al., 1998), mainly where anoxic conditions were found.

In Table 6, a comparison is made among records for specific richness, algal density, biomass, and chlorophyll $a$ registered in the reservoir for the 1987-1988 period and those of the present paper.

The phytoplankton species richness in both studied zones was generally higher on the surface. This richness was represented by 57 algal entities, whereas in the 1987-1988 period 45 species were identified (Seeligmann \& Tracanna, 1994; Martínez De Marco \& Tracanna, 2001). All the studies carried out agree that the number of green algae species is higher than that of the other groups. Increase of diatom taxons, green algae, and dinoflagelates as well as a decrease of Cyanobacteria were also observed during the 1997-1999 period.

The structure of the phytoplankton dominance showed an insignificant variation throughout the period studied, and only 17 species became numerically important in relation to their frequency and out of these, 13 were common to both sites. Martínez De Marco \& Tracanna, op. cit., for the 1987-1988 period, conside- red that 27 algal entities were relevant due to their presence in every sampling or because they were an important part of the population at some level or time of the year.

Phytoplankton was characterized at different times by the development of $A$. granulata and C. meneghiniana, these species being $84 \%$ of the whole community. Bacillariophyceae are generally pointed out as dominant for numerous worldwide water bodies, the centric forms ( $\mathrm{Au}$ lacoseira and Cyclotella), characteristic of mesotrophic to eutrophic environments being the most relevant (Huszar et al., 1998; Margalef et al., 1976; Margalef, 1983; Sastre et al., 1994; Vila et al., 1987, among others). On the surface, $A$. flos-aquae, C. acutum var. variabile and B. braunii seldom prevailed, whereas in the 1987-1988 period warm-month surface samples were different from those at other levels in both years, $M i$ crocystis aeruginosa, Chlamydomonas globosa, Monoraphidium pusillum and Volvox disipatrix being the most common ones.

Phytoplankton abundance, decreased in general with depth in the 1997-1998 stratification period, whereas during most part of the mixing period and in the 1998-1999 stratification period, maximal values were obtained at depth, in agreement with Seeligmann \& Tracanna, 1994; Martínez De Marco \& Tracanna, 2001; Sastre et al., 1994, among other authors. Margalef et al. (1976) asserted that the phytoplankton vertical distribution does not usually reach its peak on the surface, but up to $2 \mathrm{~m}$ deep. Density decrease on the surface has often been attributed to the harmful effect of a relatively short wave radiation.

When the average algal density/ml of the water column in the reservoir limnetic zone was compared with previous studies (Seeligmann \& Tracanna, 1994; Martínez De Marco \& Tracanna, 2001), an increase of $61 \%$ in the number of ind/ml was observed.

When comparing both sampling zones with regards to algal abundance, Cyanobacteria were found to be abundant only in ZI surface samples in spring 1997 and October 1998. The same can be said for Botryococcus braunii that stood out in the latter month. Algal density is generally higher at depth during a longer period in ZIR 
than in ZI, the highest density record $(988 \mathrm{mg} / \mathrm{l})$ being obtained on the surface in ZIR. In the limnetic zone and in that of the intersection of rivers between July 1998 and January 1999, the phytoplankton community was represented nearly exclusively by Aulacoseira granulata whose abundance percentages were, at every level, $76 \%-98 \%$ of the community total except in ZI where it reached the lowest value of $20.5 \%$ on the surface in October 1998.

Biomass maximal, minimal, and average values in the period studied were higher than those obtained in 1987/88 (Seeligmann \& Tracanna, 1994; Martínez De Marco \& Tracanna, 2001). In both studies the Bacillariophyceae class was the one that most contributed to the phytoplankton biomass. Seeligmann \& Tracanna op. cit. characterised the reservoir as mesotrophic. This difference in biomass could characterise Dr. C. Gelsi reservoir as eutrophic (Table 6).

Biomass average records for the 97/99 period are in agreement with the maximum values found in different environments in the USA, Russia, Austria, and Switzerland, in accordance with a worldwide bibliographical revision (García de Emiliani \& Manavella, 1983). Regarding chlorophyll $a$, the average values found were lower than those registered in the Río Hondo reservoir during sugarcane harvest time (Tracanna et al., 1999), its maximal values being lower than those determined for other Argentine reservoirs such as Los Molinos and San Roque (Córdoba) that reached values of 635 and $209 \mu \mathrm{g} / \mathrm{l}$, respectively (Rodríguez et al., 2000).

Chlorophyll $a$ may give an idea of the water eutrophication level because it is a rather precise indicator of phytoplankton biomass or pigment concentration in algal populations. The correlation between the biomass results estimated as chlorophyll $a$ and density, proves what was previously mentioned (Tables 1 and 2).

Population maximum values agreed with diversity minimum values; population growth is generally due to the excessive proliferation of very few species (A. granulata and/or C. meneghiniana) rather than to a species increase in the environment. Species diversity low values agreed with those of other Argentine reservoirs
(Margalef, 1983), while Meichtry de Zaburlín (1999) mentions, for the Yacyretá dam, values of up to 5 with average values between 4-4.7.

Pantle and Buck's Index based on saprobicity was effective in assessing water quality mainly characterized as $\beta$ - $\alpha$-mesosaprobic to $\alpha$ mesosaprobic with a prevalence of Aulacoseira granulata, a species that can be found in $\alpha$ polysaprobic to polysaprobic environments according to Mirande \& Tracanna, 2003, Seeligmann et al., 2001. This index is restricted in its use because it is closely related to reservoir's water chemistry, the species saprobic grade having been modified according to their regional behavior. As a consequence, they only agreed with the ranges given by Sládecek (1973) for Botryococcus braunii, Pandorina morum, Planktosphaeria gelatinosa, and Scenedesmus quadricauda.

When applying Principal Components Analysis in relation with the phytoplankton density and some abiotic variables, the samples from the mixing period in ZI were found to exhibit a high homogeneity and a tendency to a separation between the 97-98 and 98-99 stratification periods because the phytoplankton did not, in general, vary significantly in its composition. This can be attributed to the characteristics of the participating species that are mostly cosmopolitan (Wolf, 1982). However, the samples differed in algal concentration which depended on temperature, conductivity, $\mathrm{pH}$, dissolved oxygen, and nitrate. Component 1 exhibited spatial differences separating hypolimnetic samples and those of the first months of the mixing period mainly because the characteristics of these waters were more similar to those of the previous stratification, and axes 2 and 3 effected a temporal separation without defining markedly independent groups. With regard to ZIR components 1 and 2, spatial variability was only apparent in the 98-99 stratification period since phytoplankton, as it did in ZI, only varied particularly in the densities of the members of the community which was mainly related to most ZI abiotic variables, orthophosphate being included instead of nitrate. In axis 3 a more conspicuous separation from the different periods was found. 


\section{ACKNOWLEDGMENTS}

This research work has been financed by the CIUNT, Project 26/G229, and CONICET, PIP 0871/98.

We wish to thank the staff of the main laboratory of Obras Sanitarias Tucumán (former Aguas del Aconquija SA Company), the Centro de Investigaciones y Transferencias Químicas (CIQ) de la Facultad de Ciencias Naturales, IML de la Universidad Nacional de Tucumán, and Obras Sanitarias de la Provincia de Tucumán for carrying out the chemical analyses. We also like to thank the staff of the laboratory of El Cadillal potabilizing station for their help during field work and the Hidroeléctrica Tucumán SA Company for contributing with some technical data on the reservoir.

\section{REFERENCES}

AMOROSO, M. J., N. C. ROMERO, F. CARLINO, R. HILL, \& G. OLIVER. 1997. Mn (II) en un reservorio de agua y efecto del mismo sobre Actinomycetes acuáticos. Actas del II Congreso Argentino de Limnología. Buenos Aires: 31.

AMOROSO, M. J., G. R. CASTRO, F. J. CARLINO, N. C. ROMERO, R. T. HILL \& G. OLIVER. 1998. Screening of heavy metal-tolerant actinomycetes isolated from the Salí River. J. Gen. Appl. Microbiol., 44 (2): 129-132.

APHA. 1992. Standard methods for the examination of water and wastewater. 18 th. Ed. Amer. Publ. Health Assoc. Washington. 710 pp.

ARIAS VERDES, J. A., C. RIERA BETANCOURT, D. ROJAS COMPANIONI, N. CABRERA CRUZ \& G. DIERKMEIER CORCUELA. 1992. Plaguicidas organoclorados. Centro Panamericano de Ecología Humana y Salud (Serie Vigilancia). Organización Panamericana de la Salud. Organización Mundial de la Salud. 97 pp.

ARJONA, M., M. M. DIOS, L. B. SALAS \& P. E. GÓMEZ. 2000. Caracterización físico química y biológica del dique Las Pirquitas-Provincia de $\mathrm{Ca}$ tamarca. Memorias del XVIII Congreso Nacional del Agua: 251-252.

BONETTO, A. A., D. H. DI PERSIA, R. MAGLIANESI, \& M. DEL C. CORIGLIANO. 1976. Caracteres limnológicos de algunos lagos eutróficos de embalse de la región central de Argentina. Ecosur, 3: 47-120.

BUCHER, E. H. 1980. Ecología de la fauna chaqueña: una revisión: Ecosur, 7: 111-159.

BUCHER, E. H. \& J. M. CHANI. 1998. Región 2. Chaco. En: Los humedales de Argentina: clasificación, situación actual, conservación y legislación. Canevari, P., D. E. Blanco, E. Bucher, G. Castro \& I. Davidson (eds.): 73-96. Wetlands International Publ. 46, Buenos Aires, Argentina.

CABRERA, A. L. \& A. WILLINK. 1973. Biogeografía de América Latina. Monografía de la Secretaría General de la OEA, Serie Biológica. Monografía no $13,120 \mathrm{pp}$.

CALCAGNO, A., M. FIORITI, F. PEDROZO, P. VIGLIANO, H. LÓPEZ, C. REY, M. RAZQUIN \& R. QUIRÓS (eds.). 1995. Catálogo de lagos y embalses de la Argentina. Dirección Nacional de Recursos. $151 \mathrm{pp}$.

CANEVARI, P., D. E. BLANCO, E. BUCHER, G. CASTRO \& I. DAVIDSON (eds.). 1998. Sección I. Los Humedales de Argentina. En: Los humedales de Argentina: clasificación, situación actual, conservación y legislación. P. Canevari, D. E. Blanco, E. Bucher, G. Castro \& I. Davidson (eds.): 3-24. Wetlands International Publ. 46, Buenos Aires, Argentina.

CHAILE, A. P., N. C. ROMERO, M. J. AMOROSO, M DEL V. HIDALGO \& M.C. APELLA. 1999. Plaguicidas clorados en el río Salí. Tucumán, Argentina. Rev. Bol. de Ecol., 6: 203-209.

CHAPMAN, D. \& V. KIMSTACH. 1992. The selection of water quality variables .In: Water Quality Assessments. D. Chapman (ed.). Chapman \& Hall. London. $585 \mathrm{pp}$.

CONSEJO FEDERAL DE INVERSIONES (CFI). 1962. Recursos hidráulicos superficiales. Serie Evaluación de los Recursos Naturales de la Argentina (1 $1^{\circ}$ Etapa) 4 (2). 79 pp.

DE LA CANAL \& ASOCIADOS S.R.L. 1994. Código Alimentario Argentino Actualizado. Capítulo XII, $331 \mathrm{pp}$.

DÍAZ RUEDA, O. 1988. Plan de estudios integrados de la cuenca río Sali-Dulce. Comité de cuenca Ríos Salí- Dulce, 1: 401 pp. II: planillas y planos. Subsecretaría de Recursos Hídricos de la Nación.

FERRER, C. R., F. L. PEDROZO, F. M. TIRADO, P. ARIAS \& M. I. LISSARRAGE. 2000. Evaluación física, química y trófica de las aguas del embalse 
Los Alisos, Jujuy-Argentina. Memoria del Congreso Nacional del Agua, Santiago del Estero, Argentina: 215-216.

GARCÍA DE EMILIANI, M. O. \& M. I. MANAVELLA. 1983. Fitoplancton de los principales cauces y tributarios del valle aluvial del río Paraná: tramo Goya-Diamante, II. Rev. Asoc. Cienc. Nat. Litoral, 14: 217-237.

HAMM, A. 1969. Die Ermittlung der Gewässergüteklassen bei Flie $\beta$ gewässern nach dem Gewässergütesystem und Gewässergütenomogramm. Münchner Beitr. Abwass. Fischereiund Flussbiologie, 15: 46-48.

HUSZAR, V. L. M., L. H. S. SILVA, P. DOMINGOS, M. MARINHO \& S. MELO. 1998. Phytoplankton species composition is more sensitive than OECD criteria to the trophic status of three Brazilian tropical lakes. Hydrobiologia, 369/370: 59-71.

INSTITUTO DE ARQUITECTURA Y PLANEAMIENTO. 1967. El Cadillal. Estudio de los recursos turísticos y recreativos. Facultad de Arquitectura y Urbanismo UNT. Gobierno de la Provincia de Tucumán, 44 pp., 6 mapas.

JACKSON, M. L. 1970. Análisis Químico de Suelos. Ediciones Omega, S.A. 662 pp.

KRUSE, E., R. CASANOVA Y A. FRESCA. 1994. Proceso de colmatación en embalses del noroeste argentino. Tankay, 1: 14-16.

LOCASCIO DE MITROVICH, C., A. VILLAGRA DE GAMUNDI, B. C. TRACANNA, C. SEELIGMANN Y C. BUTÍ. 1997. Situación actual de la problemática de los embalses de la provincia de Tucumán (Argentina). Lilloa, 39: 81-93.

LOEZ, C. R. 1995. Determinación de clorofila $a$. En: Ecosistemas de aguas continentales. Metodología para su estudio. G. Tell \& E. C. Lopretto (eds.): 263-269. Ediciones Sur. Tomo I.

LÓPEZ, P., J. ARMENGOL Y F. A. COMIN. 1984. Variación anual de las características químicas en la laguna de la Massona. Limnetica, 1: 1-8.

LOPRETTO, E. C. \& G. TELL (eds). 1995. Ecosistemas de aguas continentales. Metodología para su estudio. Ediciones Sur, tomo I, 377 pp.

MARGALEF, R. 1983. Limnología. Ediciones Omega Barcelona, 1010 pp.

MARGALEF, R., D. PLANAS, J. ARMENGOL, A. VIDAL, N. PRATT, A. GUISET, J. TOJA Y M. ESTRADA. 1976. Limnología de los embalses españoles. Dirección General de Obras Hidráulicas. Ministerio de Obras Públicas. Madrid. $422+75$ pp.
MARTÍNEZ DE MARCO, S. N. Y B. C. TRACANNA. 2001. Limnología del embalse Dr. C. Gelsi (El Cadillal), Tucumán - Argentina. IV: cambios espaciales y temporales del fitoplancton. $\mathrm{Li}$ lloa, 40: 223-234.

MEICHTRY DE ZABURLÍN, N. 1999. La comunidad fitoplanctónica durante las primeras etapas de llenado del embalse de Yacyretá, Argentina. Rev. de Ictiología, 7: 15-26.

MIRANDE, V. \& B. TRACANNA. 2003. El fitoplancton del río Gastona (Tucumán, Argentina) y su relación con la calidad del agua. Bol. Soc. Argent. Bot., 38: 51-64.

NEGRO, A. I., C. DE HOYOS, A. DEL RIO \& R. LE COHU. 1994. Comparación de dos comunidades fitoplanctónicas de dos embalses de reciente creación: Riaño y Valparaíso (España). Limnetica, 10: $115-121$.

PANTLE, R. \& H. BUCK. 1955. Die biologisch Überwachung der Gewässer und die Darstellung der Egerbnisse. Gas-u. Wasserfach, 96: 604.

REYNOLDS, C. S. 1980. Phytoplankton assemblages and their periodicity in stratifying lake systems. Holarctic Ecology, 3: 141-159.

REYNOLDS, C. S. 1982. Phytoplankton periodicity: its motivation, mechanisms and manipulation. Annual Report of Freshwater Biological Association 50: 60-75.

RODIER, J. 1990. Análisis de las aguas. Ed. Omega. Barcelona, España, 1059 pp.

RODRÍGUEZ, M. I., A. COSSAVELLA, C. ORONÁ, S. DEL OLMO, N. LARROSA, A. RODRÍGUEZ, M. AVENA, M. MARISCAL, E. CASTELLÓ, F. MIATELLO, M. PAGOT, G. MOYA, G. HILMAN, R. BASÁN, G. JAUREGUIALZO, N. ORMEÑO, C. BERTUCCI Y M. MARTÍNEZ. 2000. Evaluación preliminar comparativa de la calidad de agua y de sedimentos de embalses destinados al abastecimiento de agua potable del Gran Córdoba. Seminario Internacional. Identificación y control de algas en la producción de agua potable. Rosario, Santa Fe, Argentina. $11 \mathrm{pp}$.

ROHLF, F. J. 1990. NTSYS-pc. Numerical Taxonomy and Multivariate Analysis System. Version 1.60. Exeter Software. Setauket. New York. 159 pp.

ROMERO, N., M. PÁEZ Y R. CUEVAS. 1994. Evaluación bienal de la contaminación del dique de Río Hondo. Tankay, 1: 329-330.

ROTT, E. 1981. Some results from phytoplankton counting intercalibrations. Schweiz Z. Hydrol., 43/1: 35-62. 
SÁNCHEZ CASTILLO, P. M., L. CRUZ-PIZARRO \& P. CARILLO. 1989. Caracterización del fitoplancton de las lagunas de alta montaña de Sierra Nevada (Granada, España) en relación con las características físico-químicas del medio. Limnetica, 5: 37-50.

SASTRE, V., S. OTAÑO, N. SANTINELLI, M. PANGARO, G. AYESTARÁN \& M. E. IVANISSEVICH. 1994. Fitoplancton, nutrientes, manejo del embalse Florentino Ameghino y su influencia en el río Chubut (Chubut, Argentina). Naturalia patagónica, Ciencias Biológicas, 2: 59-69.

SEELIGMANN, C. Y B. C. TRACANNA. 1994. Limnología del embalse El Cadillal (Tucumán Argentina). II: Estudio cualitativo del fitoplancton. Cryptogamie, Algol., 15: 19-35.

SEELIGMANN, C., B. C. TRACANNA, S. MARTÍNEZ DE MARCO \& S. ISASMENDI. 2001. Algas fitoplanctónicas en la evaluación de la calidad del agua de sistemas lóticos en el noroeste argentino. Limnetica, 20: 123-133.

SHANNON, C. E. \& W. WEAVER. 1963. The Mathematical Theory of Communication. Univ. Illinois Press, Urbana. 177 pp.

SLÁDECEK, V. 1973. System of Water Quality from the Biological Point of View. Arch. Hidrobiol. Beih. Ergebn. Limnol., 7: 1-218 pp.

TAKIZAWA, M., R. R. COLWELL \& R. T. HILL. 1993. Isolation and Diversity of Actinomycetes in the Chesapeake Bay. Appl Environ Microbiol., 59: 997-1002.

TILMAN, G. D., S. S. KILHAM, \& P. KILHAM.
1984. A reply to Sell, Carne, and Fahnenstiel. Ecology, 65: 328-332.

TRACANNA, B. C. \& C. T. SEELIGMANN. 1992. Limnología del embalse El Cadillal (TucumánArgentina). III: Estudio cuantitativo del fitoplancton. Lilloa, 38: 65-74.

TRACANNA, B., C. SEELIGMANN \& V. MIRANDE. 1996. Estudio comparativo de dos em balses del Noroeste Argentino. Rev. Asoc. Cienc. Nat. Litoral, 27:13-22.

TRACANNA, B. C., A. VILLAGRA DE GAMUNDI, C. SEELIGMANN, C. LOCASCIO DE MITROVICH Y E. DRAGO. 1991. Limnología del embalse El Cadillal (Tucumán - Argentina) I: Variables morfométricas y fisicoquímicas. Rev. Hydrobiol. Trop., 24: 269-286.

TRACANNA, B. C., C. T. SEELIGMANN, V. MIRANDE, L. B. DE PARRA, M. T. DE PLAZA \& F. M. MOLINARI. 1999. Cambios espaciales y temporales del fitoplancton en el embalse Río Hondo (Argentina). Bol. Soc. Argent. Bot., 34: 101-105.

UTERMÖHL, H. 1958. Zur Vervollkommung der Quantitativen Phytoplankton Methodik. Mitt. Int. Verein. Limnol., 9: 1-38.

VILA, I., I. BARENDS \& V. MONTECINOS. 1987. Abundancia y distribución temporal del fitoplancton en el Embalse Rapel, Chile Central. Revista Chilena de Historia Natural, 60: 37-55.

WOLF, H. DE. 1982. Methods of coding of ecological data from Diatom for computer utilization. $M e$ dedel. Rijks Geol. Dienst., 36: 95-110. 